\title{
Analiza razvoja golf-turizma kroz paradigmu menadžmenta održivog razvoja
}

1 Aleksandar Racz

1 Zdravstveno veleučilište

\section{Sažetak}

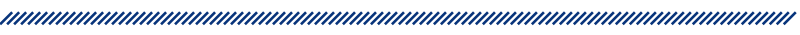

Koncepcija održivog razvoja svih segmenata društva pretpostavlja uspostavljanje pozitivnog odnosa između ekonomije i ekologije, uz bioetičko odgovorno ponašanje svih uključenih dionika. Međuzavisnost turizma i okoliša u cilju dostizanja održivog razvoja uključuje povezivanje razvojne politike $s$ menadžmentom prirodnih resursa te povećanje lokalnih kapaciteta u skladu s realnim mogućnostima okoliša. Glavni cilj ovog rada bio je, s pozicija teorijskog koncepta planiranja održivog razvoja turizma, kritički analizirati plan razvoja turističke destinacije Biograd na Moru, a posebice održivost planiranog razvoj golf-turizma na lokaciji Baštijunski brig, odnosno kritički analizirati planove izgradnje golf-igrališta s pratećim ugostiteljsko-turističkim sadržajima s aspekta ekološke, sociokulturalne, ekonomske i tehnološke održivosti kao sastavnih segmenata održivosti razvoja. Pomoćni cilj rada bila je provedba analize usklađenosti povećanje lokalnih turističkih kapaciteta kroz gradnju golf-resorta s realnim mogućnostima okoliša. U radu su korišteni sekundarni izvori informacija koji su bili podvrgnuti postupcima indukcije i dedukcije te analize i sinteze te metodama komparacije, deskripcije i klasifikacije. U praktičnom dijelu proveden je terenski izvid lokacija zahvata i mogućih kritičnih točaka prvenstveno područja dodirnih granica budućeg golf-resorta s granicama PP-a Vransko jezero, područje odlagališta otpada „Baštijunski brig” i područja ekološke mreže HR1000024 Ravni kotari i
HR2000914 Ornitološki rezervat Vransko jezero i Jasen u svrhu stjecanja neposrednog uvida u stanje na terenu i procjenu mogućeg utjecaja zahvata na okoliš. Rezultati analize, prema mišljenju autora, ukazuju da predviđena izgradnja golf-igrališta „Baštijunski brig” s pratećim ugostiteljsko-turističkim sadržajima nije u potpunosti usklađena s konceptom održivog razvoja turizma, posebice s aspekta ekološke, ekonomske i tehnološke održivosti te može voditi u prenamjenu turističke destinacije. Također, analiza upućuje na zaključak da planirana prenamjena prostora i povećanje lokalnih kapaciteta kroz gradnju golf-resorta „Baštijunski brig”, uz gradnju klastera golf-igrališta na razini županije, nije u potpunosti usklađena s realnim mogućnostima okoliša. U tom smislu razvoj cikloturizma, pustolovnog turizma, ekoturizma, a posebice „promatranja ptica” (engl. bird watching), uz snažnu oslonjenost na regionalne specifičnosti i prirodne vrednote, pruža snažnu alternativu sadašnjem razvojnom putu koji dugoročno možda nije održiv za okoliš i upitno je pridonosi li održivom razvoju turizma.

Ključne riječi: menadžment održivog razvoja, golf-turizam, zagađenje okoliša, park prirode, NATURA 2000

Datum primitka: 17.09.2017.

Datum prihvaćanja: 15.11.2017.

DOI: $10.24141 / 1 / 3 / 2 / 7$

Adresa za dopisivanje:

Aleksandar Racz

Zdravstveno veleučilište, Mlinarska cesta 38, 10000 Zagreb

Tel.: +385914595722

E-pošta: aracz@zvu.hr 


\section{Uvod}

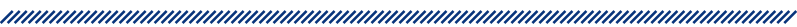

Koncepcija održivog razvoja svih segmenata društva pretpostavlja uspostavljanje pozitivnog odnosa između ekonomije i ekologije, uz bioetičko odgovorno ponašanje svih uključenih dionika ${ }^{1}$. Pri tome, u sektoru turizma razvoj koji je isključivo usmjeren na povećanje stupnja iskoristivosti postojećih i/ili izgradnju novih turističkih kapaciteta, kroz razvoj i implementaciju sadržaja kojima je cilj produženje turističke sezone i prevladavanje sezonalnosti, moguće dovodi do kratkoročnog povećanja ekonomske profitabilnosti cjelokupne destinacije. Međutim, srednjoročno i posebice dugoročno, upitna je održivost takvog razvoja, budući da planiranje koje nije provedeno prema koncepciji održivog razvoja u konačnici može dovesti do razvoja na štetu okoliša, a time izazvati trajne negativne posljedice na okoliš ${ }^{1}$.

Primjenom koncepcije održivog razvoja turizma treba maksimizirati koristi od turizma i istovremeno minimizirati štete ili troškove te usmjeriti i, ako je potrebno, ekološki i društveno odgovorno limitirati turistički razvoj, u skladu sa zahtjevima održivog razvoja turizma.

Međuzavisnost turizma i okoliša u cilju dostizanja održivog razvoja uključuje povezivanje razvojne politike $s$ menadžmentom prirodnih resursa na temelju projekata, planova i programa, povezivanje razvoja turizma i politike menadžmenta prirodnih resursa na lokalnoj, regionalnoj i državnoj razini te konačno povećanje lokalnih kapaciteta u skladu s realnim mogućnostima okoliša, posebno u područjima gdje se planira intenziviranje turističkih kretanja ${ }^{1}$.

Navedeno treba sagledavati u kontekstu činjenice da se Hrvatska s ulaskom u EU suočava s novim izazovima, ali i s novim prilikama u turizmu. Hrvatska pripada zemljama koje privlače posjetitelje više odlikama svojega prirodnog prostora i bogatstvom kulturno-povijesne baštine nego kvalitetom, raspoloživošću i/ili raznovrsnošću novostvorenih turističkih atrakcija.

Europska unija prepoznaje Hrvatsku kao turističku destinaciju s potencijalom pa je cilj državne sektorske politike maksimalno iskoristi vlastite potencijale, a u interesu rasta svekolikoga hrvatskog blagostanja,primjenjujući konkurentske strategije EUa i uvažavajući vrijednosni sustav održivog razvoja². U tom pravcu nužno je razviti cjelovit konceptualni okvir koji omogućava koordinirano djelovanje nositelja turi- stičke politike i sustavno usuglašavanje mjera turističke politike, cjelovito razumijevanje ključnih pravaca razvoja hrvatskog turizma kao preduvjeta privlačenja interesa potencijalnih domaćih i stranih ulagača te ciljano usmjeravanje razvojno-investicijskog procesa i efikasno povlačenje sredstava fondova EU-a. Svrha je ovog rada pokušati u jednom malom segmentu barem malo doprinijeti ostvarivanja navedenog.

U ovom su trenutku dominantni proizvodi hrvatskog turizma „sunce i more”, uz relativno razvijen nautički, kulturni i kongresni turizam, međutim Hrvatskoj danas nedostaju centri cjelogodišnjega planinskog i sportskog turizma, kvalitetne biciklističke staze s potrebnom infrastrukturom i suprastrukturom, ronilački i jedriličarski centri te drugi sadržaji nužni za kvalitetno i dugoročno održivo tržišno pozicioniranje na tržištu posebnih interesa² ${ }^{2}$.

U segmentu proizvoda s izraženom perspektivom razvoja, osim zdravstvenog turizma, cikloturizma, gastronomije i enologije, planinskog i ruralnog turizma i ekoturizma, planira se intenzivan razvoj golf-turizma.

Uz neupitnu povezanost sporta i turizma ${ }^{3}$, razvojni potencijal golf-turizma leži u procijenjenih oko 60 do 70 milijuna igrača i više od 34000 igrališta na svijetu s više od 576000 rupa. Uvažavajući navedeno, golf-turizam početkom 21. stoljeća predstavljao je potencijalno visoko prihodovnu djelatnost ${ }^{4}$, a Vlada RH vidjela je priliku u realizaciji znatnih mogućih prihoda od golf-turizma, pretpostavivši da Hrvatska u tom segmentu ima izvanrednu komparativnu prednost kao najbliža topla destinacija s gotovo netaknutom prirodom u kojoj golferi s velikog tržišta srednje i istočne Europe mogu igrati golf gotovo cijelu godinu.

U tom smislu na golf se gledalo kao na mogući pokretač turističkog razvoja ${ }^{5}$ te se smatralo da bi se razvojem golf-turizma u Hrvatskoj dao znatan doprinos rješavanju dijela kroničnog problema sezonalnosti ${ }^{6}$, pogotovo u obalnom području, pretpostavivši da bi golf-turisti mogu napuniti sada slabo popunjene postojeće kvalitetne hotelske kapacitete izvan glavne turističke sezone i pridonijeti znatnom rastu izvanpansionske potrošnje? Vlada RH smatra da golf-turizam predstavlja mogućnost još uspješnije gradnje imidža Hrvatske kao elitne destinacije, jer se navodno nemogućnost igranja golfa u međunarodnoj javnosti sve češće naglašava kao na ozbiljan minus hrvatske turističke ponude. Neki autori navode da bi turizam Hrvatske izgradnjom golf-igrališta dobio na atraktivnosti i ekskluzivnosti ponude, da bi poslovnim partnerima hrvatskih poduzetnika bili ponuđeni bogatiji sadržaji i ponuda tijekom boravka u Hrvat- 
skoj te da razvoj golfa podrazumijeva nove poslove i za domaća poduzeća, od projektiranja i izgradnje igrališta do marketinga turnira i smještaja gostiju ${ }^{8}$.

U skladu s navedenim, na području turističke destinacije grada Biograda na Moru, već se desetak godina na destinaciji Baštijunski brig planira izgradnja golf-igrališta i pratećeg resorta koji bi obuhvaćao površinu od više od 140 ha. Namjeravani zahvat izgradnje golf-igrališta na destinaciji Baštijunski brig dio je Strategije razvoja grada Biograda na Moru i Zadarske županije, a trebao bi biti sastavni dio programa razvitka golfa kao elementa razvojne strategije hrvatskog turizma koje je Ministarstvo turizma predložilo, a Vlada Republike Hrvatske prihvatila i potvrdila zaključkom na sjednici održanoj 26. kolovoza 1999. ${ }^{9}$ Planirano područje destinacije Baštijunski brig smješteno je $1,5 \mathrm{~km}$ sjeverozapadno od Vranskog jezera, čija je blizina iznimno važna i zahtijeva pomno proučavanje i kritičku analizu razvojnih planova kroz paradigmu menadžmenta održivog razvoja turizma, posebice budući da se kao najčešća prijetnja održivom razvoju turizma naglašava segment održivog razvoja okoliša. Naime, prilikom izgradnje golf-terena u sklopu cjelokupnog resorta posebno se izdvajaju problemi povezani s korištenjem prostora i intervencije u okolišu i krajobrazu koje dovode do gubitaka prirodnih površina, zahtijevaju dodatne velike potrebne količine vode za natapanje biljnih površina, održavanje zelenila travnate površine uz nužnost upotrebe pesticida i gnojiva te mogući negativan utjecaj na bioraznolikost, a cjelokupne aktivnosti razvoja golf-turizma mogu voditi šteti u vrijednim prirodnim bogatstvima.

Predmet posebnog izučavanja ovog rada odnosi se analizu razvoja golf-turizma kroz paradigmu menadžmenta održivog razvoja na primjeru turističke destinacije grada Biograda na Moru, konkretno na lokaciju zahvata područja Baštijunski brig u zaleđu Biograda na Moru. Naime, tamo je predviđana izgradnja golf-igrališta na 140 ha sa svim pratećim sadržajima gospodarske - ugostiteljsko-turističke namjene, što sve zajedno predstavlja jedinstvenu funkcionalnu i prostornu cjelinu koja predstavlja složenu građevinu.

Kritička analiza održivosti razvoja destinacije posebno je važna budući da prostor predviđenog zahvata zadire i u područja zaštićena programom NATURA 2000 i moguće je da bi u jednom trenutku došlo do smanjenja obuhvata PP-a Vransko jezero nauštrb planirane golf-investicije, što nije nelegitimno, ali traži širu analizu problema i konsenzus struke.

Osim ekološkog, s aspekta menadžmenta održivog razvoja važan je, iako zasad zanemarivan, mogući utjecaj i na lokalno društvo i stanovništvo, kao i pritisak prometa povezanog s dolaskom na destinaciju i ostalo.

S aspekta ekološke održivosti važno je osvijestiti da se prilikom održavanja izgrađenog golf-igrališta, osim utjecaja na krajobraz, multipliciraju i drugi negativni utjecaji na okoliš. Prvenstveno treba istaknuti mogući izrazito negativan utjecaj na vodoopskrbu, s obzirom na to da se voda na igralištu upotrebljava za sanitarnopotrošne namjene, a drugi, znatniji dio za zalijevanje. Godišnja potrošnja vode za zalijevanje travnjaka ovisi o klimatskim uvjetima (temperaturi, vlazi, vjetru, padalinama, izloženosti), morfologiji i strukturi tla, vrsti travnjaka, načinu upravljanja travnatim površinama, pritisku prometa i rasponu zalijevanih površina. Posebno intenzivno zalijevanje vrši se na početnim i završnim područjima igrališta, uključivši i rubna područja, površinama staza (posebno mjesta očekivanog doleta loptice) te rubna područja staza. Ostala područja igrališta uglavnom se ne zalijevaju, već se prepuštaju prirodnom režimu navodnjavanja. Kako bi se smanjila potrošnja vode za zalijevanje, sve veća pažnja usmjerava se na selekciju trava, predstavnika autohtone flore ili na izbor suši otpornijih varijeteta, a također se povećava pažnja o kvaliteti tla, tj. supstrata.

Uz to što se opterećuje postojeća vodoopskrbna mreža i direktno povećava zahvat (pitke) vode iz rezervoara, što može voditi u salinizaciju postojećih izvora, održavanjem golf-terena povećava se mogućnost kontaminacije ograničenih podzemnih ležišta pitke vode aplikacijom gnojiva. Količina korištenog gnojiva ovisi o vrstama trave (specifične potrebe), vrsti tla, vrsti korištenog gnojiva (npr. gnojivo koje sadrži dušik može ga otpuštati sporije ili brže), brzini rasta trave, metodi primjene (npr. tekuće ili kruto), hranjivim sastojcima koji su već prisutni u tlu i - odstranjivanju pokošene trave.

Golf-igrališta zadiru u brojna staništa cijelog niza raznih biljnih i životinjskih vrsta, od kojih mnoge polako nestaju iz prirodnog okruženja kao posljedica narušavanja ili nestanka potrebnih prirodnih područja, lova te fitosanitetskih proizvoda koji se sve više primjenjuju u poljoprivredi. Na lokaciji Baštijunski brig to je izrazito velik problem zbog dodirivanja i preklapanja s Ornitološkim rezervatom Vransko jezero, Parkom prirode Vransko jezero i krškom terenu s podzemnim tokovima vode.

Analiza održivosti razvoja golfa na lokaciji Baštijunski brig mora se sagledavati i na razini planova razvoja i drugih turističkih destinacija na području obližnjih okolnih mjesta i gradova (Sv. Filip i Jakov, Pakoštane), budući da ovo golf-igralište nije i jedino planom pred- 
viđeno golf-igralište. Konkretno, u skladu s činjenicom da se na destinaciji koja se odluči usmjeriti na golf-turizam stvaraju tzv. golfski klasteri, područja s pet ili više igrališta koja sa smještajnim kapacitetima u okolici čine prepoznatljiva turistička odredišta, ni ovdje planovi za izgradnju rečenog golf-igrališta nisu i jedini predviđeni tereni. Primjer su preizgrađeni klasteri na području portugalske regije Algarve ${ }^{11,10}$, turske regije Antalya te španjolskih regija Costa del Sol i Mallorca.

Uz golf se često vežu turizam i prodaja nekretnina te je stoga investiranje u golfersko-turističku sferu unosnije od klasične investicije u nekretnine. Gradnja nekretnina, a posebice apartmana u sklopu golf-kompleksa opravdava se početnom nerentabilnošću golfa i amortizacije održavanja igrališta. Investiranje u klasično golfigralište bez nekretnina podrazumijeva dugo vraćanje uloženog kapitala (i do 40 godina), što predstavlja velik rizik za investitore ${ }^{7}$ I I na području Baštijunskog briga planira se izgradnja hotela, vila i apartmana s kapacitetima koji premašuju postojeće hotelske kapacitete Biograda na Moru, što zapravo upućuje na to da je možda riječ o prenamjeni destinacije.

Analiza održivosti razvoja turizma u zaleđu Zadarske županije važna je i budući da je, uz apartmanizaciju, golf u nekim sredinama postao izgovor za urbanizaciju, a česte su zamjerke da se područje planirano za golf zatvara, tj. izdvojeno razvija bez povezanosti s lokalnom zajednicom. Upravo suprotno, planiranje održivog razvoja turizma pretpostavlja zadovoljenje potreba $\mathrm{i}$ unaprjeđenje kvalitete života lokalnog stanovništva te uključuje i očuvanje sociokulturnog identiteta lokalne zajednice, razvijanje visokokvalitetnoga turističkog proizvoda, unaprjeđenje kvalitete doživljaja turista i očuvanje resursa kako bi se i buduće generacije mogle njima koristiti te se iz navedenog izvodi doprinos blagostanju stanovništva.

Prema svemu navedenom, potrebno je, polazeći od koncepta održivog razvoja turizma, kritički analizirati, kroz paradigmu menadžmenta održivog razvoja, razvoj turističke destinacije Biograd na Moru, usmjeren kroz predviđenu izgradnju golf-igrališta „Baštijunski brig”, pri čemu analiza mora biti šira i sveobuhvatnija od jednostavne procjene prihvatljivosti zahvata samo za okoliš, a uz primjenu mjera zaštite okoliša i programa praćenja stanja okoliša koje su iznesene u SUO-u, a koje ionako naručuje i plaća investitor.

Neosporno je da dugoročni cilj održivog razvija turizma podrazumijeva razvoj novih turističkih proizvoda, višu kvalitetu smještajnih kapaciteta, povećanje turističke potrošnje, veće zapošljavanje, rast investiranja i smanjenje sezonalnosti, međutim konačni cilj tako koncipiranog razvoja mora biti održivost, dakle blagostanje za sadašnje i buduće generacije, bez čega nema dugoročne održivosti razvoja turizma.

U skladu $\mathrm{s}$ navedenim, projekt izgradnje golf-terena na području Baštijunskog briga, kao i strategija razvoja turizma lokalne zajednice i županije, mora se kritički analizirati kako bi se dao doprinos optimizaciji potencijalnog doprinosa turizma ljudskom blagostanju i kvaliteti uz očuvanje resursa kako bi se i buduće generacije mogle njima koristiti.

\section{Cilj istraživanja}

Glavni cilj ovog rada bio je, s pozicija teorijskog koncepta planiranja održivog razvoja turizma, kritički analizirati plan razvoja turističke destinacije Biograd na Moru, a posebice održivost planiranog razvoja golf-turizma u zaleđu Biograda na Moru na lokaciji Baštijunski brig, odnosno kritički analizirati izgradnju golf-igrališta s pratećim ugostiteljsko-turističkim sadržajima s aspekta ekološke, sociokulturalne, ekonomske i tehnološke održivosti kao sastavnih segmenata održivosti razvoja turizma. Posebna pažnja posvećena je i analizi međusobne usklađenosti lokalnih razvojnih turističkih planova na lokacijama u zaleđu Zadarske županije, u blizini PP-a Vransko jezero, te njihove usklađenosti sa strateškim ciljevima razvoja turizma prema vrijedećoj Strategiji u kojoj je naglasak na „izgradnji okolišno osjetljivih i igrališta projektiranih u skladu s prirodnim okruženjem" u Hrvatskoj, kao i analizi povezanosti usvojene razvojne politike grada Biograda na Moru s menadžmentom prirodnih resursa, a na temelju dostupnih projekata izgradnje, planova i programa9

Pomoćni cilj rada bila je provedba analize usklađenosti povećanje lokalnih turističkih kapaciteta kroz gradnju klastera golf-igrališta i golf-resorta s realnim mogućnostima okoliša, koja se temelji ne samo na dostupnim dokumentima nego i na terenskom izvidu na lokaciji planiranog zahvata.

Sobzirom na to da su prostor i čovjekova okolina imanentni pojmu turizma, a turizam je nezamisliv bez komponente prostora i čovjekove okoline, definiranje okoline, 
njezina valorizacija i izbor optimalnih pravaca korištenja daju mogućnost utvrđivanja optimalnoga turističkog potencijala određenog okruženja i prostora. U skladu s time, svrha je rada kroz kritičku analizu postojećeg stanja i procjenu mogućega budućeg utjecaja projekta razvoja golf-turizma dati određen, barem i simboličan, teorijski doprinos predviđanju, oblikovanju i usmjeravanju razvoja turizma, prostora i čovjekove okoline na primjeru grada Biograda na Moru te dati poticaj integralnom planiranju razvoja zaleđa Zadarske županije te potaknuti razvoj moguće alternative postojećem planu razvoja turističke destinacije - Biograda na Moru.

\section{Hipoteze istraživanja}

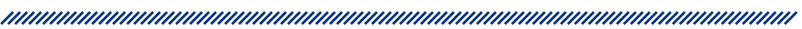

U skladu s postavljenim ciljevima postavljene su hipoteze istraživanja.

\section{Glavna hipoteza}

Urbanističkim planom i Strategijom razvoja grada Biograda na Moru predviđena izgradnja golf-igrališta „Baštijunski brig” s pratećim ugostiteljsko-turističkim sadržajima nije u potpunosti usklađena s konceptom održivog razvoja turizma, posebice s aspekta ekološke, ekonomske i tehnološke održivosti, te vodi u prenamjenu turističke destinacije.

\section{Pomoćna hipoteza}

Prenamjena prostora i povećanje lokalnih kapaciteta kroz gradnju golf-resorta „Baštijunski brig” uz gradnju klastera golf-igrališta nije usklađena s realnim mogućnostima okoliša.

\section{Metodologija}

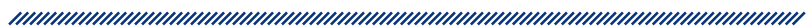

$\mathrm{U}$ radu su upotrebljavani sekundarni izvori informacija (urbanistički planovi, strategije razvoja turizma $\mathrm{RH}$, Strategije razvoja grada Biograda na Moru i Zadarske županije, SUO golf-igrališta „Baštijunski brig”, odluke nadležnih tijela lokalne uprave i samouprave, stručne studije, natječaji, medijski napisi itd.) koji su bili podvrgnuti postupcima indukcije i dedukcije te analize i sinteze te metodama komparacije, deskripcije i klasifikacije. U praktičnom dijelu proveden je terenski izvid lokacija zahvata predviđenih urbanističkim planom uređenja golf-igrališta i izgradnje golf-resorta „Baštijunski brig” te terenski izvid mogućih kritičnih točaka na lokaciji zahvata, prvenstveno područja dodirnih granica budućeg golf-resorta s granicama PP-a Vransko jezero, područje odlagališta otpada „Baštijunski brig” i područja ekološke mreže HR1000024 Ravni kotari i HR2000914 Ornitološki rezervat Vransko jezero i Jasen u svrhu stjecanja neposrednog uvida u stanje na terenu i procjenu mogućeg utjecaja zahvata na okoliš.

\section{Rezultati istraživanja}

Prostor grada Biograda na Moru ima važan centralni položaj na prostoru jadranske obale, u dijelu sjeverne Dalmacije, između dva urbano jaka gravitacijska centra (Zadra i Šibenika).

Povijesno, prostorno, ekonomski i kulturno Biograd na Moru uvijek je gravitirao, odnosno nalazio svoje mjesto u sklopu zadarske urbane regije kao prostorne cjeline širih okvira.

Značaj i posebnosti geografskog položaja grada Biograda na Moru očituju se u mediteranskoj klimi, maritimnoj eksponiranosti, plodnom zaleđu Ravnih kotara, zalihama vode u neposrednoj okolici, nepostojanju relevantnih gradskih središta u širem prostornom okruženju te preduvjetima za kvalitetno prometno povezivanje ${ }^{12}$.

Grad Biograd predstavlja idealnu polazišnu točku za istraživanje okolice, ali i udaljenijih atrakcija duž čitave obale, budući da se nalazi negdje na polovici puta između najsjevernijeg i najjužnijeg ruba hrvatskog dijela Jadranskog mora. Već u samoj bližoj okolici nalaze se čak tri nacionalna parka, dva parka prirode te nekoliko povijesnih gradova. U zaleđu grada Biograda na Moru prostire se Vransko jezero, park prirode i prirodni ornitološki rezervat, stanište velikog broja rijetkih ptica močvarica. $\mathrm{U}$ akvatoriju ispred grada Biograda na Moru prostire se Nacionalni park Kornati, koji s oko 150 otoka, otočića i hridi čini otočno najbrojniju skupinu na Sredozemlju ${ }^{12}$. 
Grad Biograd na Moru prema zadnjem popisu stanovništva iz 2011. godine ima 5569 stanovnika. Od 1953. godine broj se stanovnika više nego udvostručio te se bilježi stalan porast broja stanovnika uz neznatan pad u 2011. godini. Glavnim planom razvoja Zadarske županije za razdoblje od 2013. do 2023.godine kao sektorskim planskim dokumentom predviđen je razvoj destinacije Biograd na Moru kao dijela tzv. biogradske rivijere površine 165,73 km², a koju čine grad Biograd na Moru i općine Sv. Filip i Jakov i Pakoštane. Očuvani i zaštićeni dijelovi prirode važan su razvojni resurs. Nažalost, uslijed manjka planiranja i stihijske urbanizacije dijelovi ove baštine nepovratno su izgubljeni. Prema podacima Prostornog plana Zadarske županije (2006.), na području Biograda na Moru nalaze se zaštićena područja prirode koja uključuju: Park prirode Vransko jezero, skupinu stabala (drvored čempresa - Biograd na Moru), osobito vrijedna područja i dijelove prirode koji se predlažu za postupak uvođenja u registar (Soline - Biograd n na Moru) te područja i lokalitete osobitih bioloških i krajobraznih vrijednosti (krški ekološki sustavi, močvarni i vodeni ekosustavi, područja prekrivena autohtonom vegetacijom, more i podmorje) i SPA područja (područja važna za ptice EU-a) - Vransko jezero ${ }^{12}$.

Glavni je cilj razvoja turizma biogradske rivijere do 2020. godine povećanje njezine atraktivnosti i konkurentnosti, što bi trebalo rezultirati prepoznatljivošću biogradske rivijere po kriteriju konkurentnosti. Istodobno, ostali su strateški ciljevi turističkog razvoja do 2020. godine poboljšavanje strukture i kvalitete smještaja uz kontinuirano povećanje udjela hotela te podizanje kvalitete smještaja u kampovima i kućanstvima uz opadanje njihovih udjela u ukupnom smještajnom kapacitetu, novo zapošljavanje uz otvaranje novih radnih mjesta, pokretanje i realizacija novih investicija te povećanje turističke potrošnje ${ }^{12}$.

Također, polazeći od globalnih trendova na turističkom tržištu i kvalitete resursno atrakcijske osnove, odnosno razvojnih potencijala pojedinih proizvoda, za razvoj turizma biogradske rivijere do 2020. godine, uz sunce $\mathrm{i}$ more, istaknuta je posebna važnost stavljanja golf-igrališta i pratećih objekata u funkciju, čime će se pridonijeti promjeni percepcije Biograda na Moru ${ }^{12}$.

Prema planovima, za razvoj golfa predviđeno je oko 5.000.000 eura. lako nije naveden kao prioritet, za projekt izgradnje golf-terena privatnog investitora proveden je SUO, a 2016. godine ishođena je građevinska dozvola za treću fazu izgradnje (klasa: UP/l-361-0311 4-12110, urbroj: 21981 1-11-211-16-9, Biograd n/m, 4. kolovoza 2016.) kojom se investitoru trgovačkom društvu Golf Centar Biograd d.o.o., Zagreb, Ulica grada Vukovara $269 \mathrm{D}$, dozvoljava treća faza izgradnje igrališta za golf „Baštijunski brig” - parkiralište s komunalnom infrastrukturom, na građevnoj čestici katastarske oznake kat. čest. broj 6991/2 u površini od $6834 \mathrm{~m}^{2}$ nove izmjere k. o. Biograd n/m $\mathrm{m}^{13}$.

Nadalje, Odlukom o Prostornom planu uređenja Grada Biograda na Moru iz listopada 2016. (Službeni glasnik 8/16) odobreni su uvjeti za gradnju i uređenje zona golf-igrališta sa smještajnim kapacitetima i pratećim sadržajima ${ }^{14}$.

Fond za zaštitu okoliša odobrio je sredstva u iznosu od 30.000.000 kn za sanaciju odlagališta otpada „Baštijunski brig", kao preduvjet za izgradnju golf-igrališta u čijem se prostornom sklopu danas nalazi divlji deponij.

\subsection{Kritički osvrt na projekt razvoja golf- turizma u zaleđu Biograda na Moru}

U smislu strateškog „modela 4P” (engl. Place, Price, Product, Promotion; hrv. mjesto, cijena, proizvod, promocija), pravilno pozicioniranje na turističkom tržištu zahtijeva kontinuirano praćenje tržišta (cijene i usluge) te usklađivanje s turističkim trendovima. Također je nužno pravodobno uočiti nove tržišne prilike (tražena razina usluga, nova emitivna tržišta i sl.) područja mogućih ulaganja i prilagoditi infrastrukturu novim potrebama ${ }^{12}$.

Prema Strategiji razvoja turizma do 2020. godine, razvoj golf-terena procijenjen je kao prilika te je u skladu sa Strategijom predviđena izgradnja do 30 golf-terena od kojih je najviše grozdova smješteno u Istru, međutim izgradnja golf-terena predviđena je i u ostalim županijama. Strategijom se u Zadarskoj županiji u sklopu projekta „Baštijunski brig” predviđa izgradnja golf-terena u neposrednoj blizini granica PP-a Vransko jezero i na području antičkih nalazišta upisanih u kulturnu baštinu RH.

Međutim, analiziraju li se prostorni planovi županija, u Hrvatskoj je, prema vrijedećim prostornim planovima, predviđena gradnja ukupno 89 igrališta za golf. Premda je za većinu iskazana ukupna površina parcela, u prosjeku između 70 i 120 hektara, za većinu se ne zna koliko bi rupa (polja) ti tereni trebali imati.

U Zadarskoj županiji planirana je gradnja 15 golf-igrališta, i to: Benkovac (Miranje Donje 100 ha), Biograd na Moru („Baštijunski brig” 140 ha), Gračac (Ogreci - Mazin 201 ha), Nin (Ninski stanovi 113 ha), Novigrad (Ladina 100 ha), Obrovac (Župani 150 ha), Pakoštane (Gradina, Vrana 124 ha, Umac - Vlake, Vrana 132 ha, „Baštijunski brig" 80 ha), Posedarje (Svrdlac - Ivandići 71 ha), Sukošan (Tustica 160 ha), Zadar (Bokanjac 123 ha, Diklo 
97 ha, Viševica - Petrčane 140 ha) i Zadar - Nin (Šepurine - Punta Skala 71 ha).

U susjednoj Šibensko-kninskoj županiji planirano je samo jedno igralište na lokaciji Skradin (Prukljan) veličine 67 ha.

Broj predviđenih golf-terena na području Zadarske županije nije usklađen sa Strategijom razvoja na razini $\mathrm{RH}$, a veličina igrališta prema broju predviđenih rupa nije do kraja razvidna. Tek se neslužbeno procjenjuje da je u većini slučajeva riječ o igralištima sa 18 ili čak 27 rupa, odnosno o klasi natjecateljskih igrališta, budući da se, prema stajalištima čelnika lokalne uprave i samouprave, manja igrališta uopće ne isplate.

Planirano područje destinacije Baštijunski brig smješteno je oko $4 \mathrm{~km}$ od obale mora i 1,5 km sjeverozapadno od Vranskog jezera. Upravo je blizina PP-a Vransko jezero iznimno važna pri izradi studije utjecaja na okoliš i ogledni primjer koji pruža odgovor je li uopće moguće uklopiti izgradnju golf-igrališta u blizini zaštićenoga prirodnog prostora, budući da se uz golf-igralište na destinaciji predviđa gradnja svih pratećih sadržaja gospodarske namjene - ugostiteljsko-turističke djelatnosti, u što su uključeni sljedećih dijelovi: gospodarska zona - ugostiteljsko-turistička namjena, golf-igralište (prva i druga faza), klupska kuća, servisna kuća, zaštitne zelene površine, javne zelene površine, rasadnik, vodne površine (jezera i kanali) i površine infrastrukturnih sustava. Teren za golf sadržavao bi tri golf-igrališta, svako s po devet polja, što čini ukupno 27 polja, te golf-vježbalište. U prvoj fazi gradila bi se dva golf-igrališta s devet polja i golf-vježbalište, a u drugoj fazi izgradilo bi se još jedno golf-igralište s devet rupa ${ }^{13}$.

Lokacija zahvata smještena je u zaleđu grada Biograda na Moru, sjeverozapadno od Vranskog jezera, neposredno uz granicu prostora Općine Pakoštane. Od mora je udaljena oko $2,5 \mathrm{~km}$ zračnom linijom. Za planirani zahvat relevantni su sljedeći dokumenti prostornog uređenja: Program prostornog uređenja RH (NN 50/99). Prostorni plan Zadarske županije (Službene novine Zadarske županije, broj 2/01, 6/04), Prostorni plan uređenja grada Biograda na Moru (Službeni glasnik grada Biograda $n / m$, broj 9/05, 3/09), Program mjera za unapređenje stanja u prostoru na području grada Biograda n $/ \mathrm{m}^{14}$, Urbanistički plan uređenja golf igrališta „Baštijunski brig”"15.

Mikrolokacijski, lokacija golf-igrališta nalazi se sjeverno od Parka prirode Vransko jezero, i to na oko $1 \mathrm{~km}$ udaljenosti. Lokaciji se prilazi djelomice neasfaltiranim putem dužine oko 600 do 1000 m, koji se odvaja od prometnice D503 Biograd na Moru - Benkovac (sa sjeverne strane).
Također se lokaciji može prići i s južne strane iz smjera Vranskog jezera.

U skladu s Uredbom o proglašenju ekološke mreže (NN 109/07), lokacija zahvata golf-igrališta „Baštijunski brig" ulazi u područje mreže HR1000024 Ravni kotari međunarodno važna područja za ptice ${ }^{16}$.

Izvan granica šireg područja lokacije planiranog zahvata nalazi se područje ekološke mreže HR1000025 Vransko jezero (lokacija golf igrališta nalazi se oko $1 \mathrm{~km}$ sjeverno od Parka prirode Vransko jezero) i Jasen - međunarodno važna područja za ptice te HR2000914 Ornitološki rezervat Vransko jezero i Jasen - važna područja za divlje svojte i stanišne tipove ${ }^{13}$.

Područje predviđene lokacije izgradnje golf-igrališta „Baštijunski brig” nalazi se u državnom otvorenom lovištu XIII/33 „Vrana”, koje je ustanovljeno na području Zadarske i Šibensko-kninske županije. Lovište je brdskog tipa, a obuhvaća brdovit teren šumskog predjela Crna gora iznad Vranskog jezera, dok je jugozapadni dio terena ravničarski s manjim močvarnim površinama, gdje se i nalazi buduće golf-igralište ${ }^{16}$.

S aspekta menadžmenta održivog razvoja važno je također da okolne općine imaju izvanredne uvjete za razvoj poljoprivrede, gdje se posebno ističe prostor Vranskog bazena kao jedno od najvažnijih poljoprivrednih potencijala mikroregije, što je važno prilikom procjene isplativosti izgradnje terena i mogućeg utjecaja na poljoprivrednu proizvodnju hrane u okolici.

Prema SUO-u, predviđa se da unutar obuhvata UPU-a (140,00 ha) neizgrađene površine zauzmu 126 ha, što iznosi 90,00 \% ukupne površine obuhvata, od čega bi na zaštitno zelenilo otpadala površina od 6,90 ha, što čini $5,48 \%$ neizgrađenih površina ${ }^{13}$.

U sklopu ove zone predviđa se izgradnja hotela, vila i apartmana. Dođe li do izgradnje, hotel bi imao ukupnu površinu od cca $5000 \mathrm{~m}^{2}$, katnosti najviše $\mathrm{P} 0+\mathrm{P}+2 \mathrm{k}+\mathrm{Pk}$, visine do $11,00 \mathrm{~m}$, s najmanje četiri zvjezdice. Hotel bi trebao imati $25 \%$ ukupnoga smještajnog kapaciteta, što podrazumijeva cca 175 kreveta. Hotel i hotelska infrastruktura zauzet će cca 1,16 ha. Vile bi bile minimalne kategorije pet zvjezdica te bi sadržavale $60 \%$ ukupnog smještajnog kapaciteta maksimalno 420 kreveta. Vile će biti maksimalne katnosti $\mathrm{P} 0+\mathrm{P}+1 \mathrm{k}+\mathrm{Pk}$ visine do $8,00 \mathrm{~m}$. Apartmanske građevine bile bi minimalno kategorije tri zvjezdice, a u ukupnom kapacitetu sudjelovale bi sa $15 \%$, što znači maksimalno 105 kreveta. Apartmanske građevine imale bi maksimalnu katnost $P 0+P+1 k+P k$ visine do 
$8,00 \mathrm{~m}$. Vile i apartmani imali bi cca $25000 \mathrm{~m}^{2}$, a zauzimali bi površinu od cca 12,84 ha. Predviđa se izgradnja 114 vila i 10 apartmanskih građevina. Područje klupske kuće obuhvaćalo bi cca 0,21 ha. Na tom bi području osim klupske kuće bilo smješteno parkiralište, servisne zgrade te ostali prateći sadržaji. Područje servisne kuće obuhvaćalo bi površinu od cca 0,1 ha. Ovo područje uključuje sve servisne zgrade namijenjene održavanju kompleksa golf-igrališta, kao i prostore za smještaj radnika na održavanju i servisiranju svih sadržaja unutar predmetnog plana. Zaštitno i pejzažno zelenilo pretežno bi bio neizgrađeni prostor. Zaštitne zelene površine obuhvaćale bi 6,9 ha prostora ${ }^{13}$.

U sklopu obuhvata zahvata smješteno je odlagalište otpada kojim se koriste grad Biograd na Moru te općine Pakoštane, Sv. Filip i Jakov, Tkon i Pašman, „Baštijunski brig", koje bi se trebalo sanirati neovisno i paralelno s izgradnjom golf-igrališta. Obuhvaća površinu od cca 10,60 ha i definirano je kao javna zelena površina. Navedena površina predviđena je za uzgoj travnih površina niskog i visokog raslinja za potrebe održavanja i sanacija golf-igrališta te uređenja zaštitnih i javnih zelenih površina, kao i hortikulturno opremanje zelenila unutar infrastrukturnih površina. U okviru površina ove namjene moguća je izgradnja staklenika i plastenika te gradnja građevine za smještaj alata i pribora, kao i prostora za zaposlenike do maksimalne površine $100 \mathrm{~m}^{2}{ }^{13}$

SUO-om je utvrđeno da se na lokaciji zahvata nalazi antički objekt i zona koja je upisana u Registar kulturnih dobara Republike Hrvatske - Listu preventivno zaštićenih kulturnih dobara (klasa: UP-I-612-08-09-05/0186, urbroj: 532-04-17/9-09-1). To su arheološki ostaci iz više povijesnih razdoblja, i to: prapovijesni lokalitet, villa rustica, antički objekt manjih dimenzija, antički ili srednjovjekovni kamenolom i srednjovjekovno naselje. Zbog toga je na lokaciji zahvata provedeno arheološko rekognosciranje terena kojim su utvrđena tri dosad nepoznata arheološka lokaliteta, od čega jedan prapovijesnoga, jedan antičkoga i jedan antičko-srednjovjekovnog postanka, koji se svi nalaze nekoliko desetaka metara unutar kamenite zaravni, ali u neposrednoj blizini plodnih površina koje je okružuju ${ }^{13}$.

Najvažnije je bez sumnje bilo otkriće srednjovjekovnog sela. S obzirom na to da se dva od tri lokaliteta nalaze na rubnom području predviđenog golf-igrališta, postoji opasnost da budu ugroženi „sekundarnim” djelovanjem ili prolaskom teške mehanizacije.

Prilikom procjene mogućih negativnih utjecaja na okoliš za razumijevanje mogućeg utjecaja na okoliš na lo- kaciji izgradnje golf-terena bilo je vrlo važno detaljno istražiti geološki sastav tla, što je direktno povezano s vodoopskrbom cijelog područja golf-terena i okolice.

Bušenjem tri geotehničke sonde $\mathrm{s}$ uzorkovanjem ustanovljeno je da do dubine bušenja od $30 \mathrm{~m}$ na lokaciji podlogu čini jako razlomljena i okršena vapnenačka stijenska masa. Generalno, na lokaciji budućeg golf-centra, slojevi se pružaju smjerom sjeverozapad-jugoistok (NW-SE) s padom slojeva prema jugozapadu (SW) pod kutom od 10 do 30 stupnjeva ${ }^{13}$.

Raspucala i okršena stijenska masa propusna je za vodu ( $k$ - Darcyjev koeficijent hidrauličke provodljivosti reda je veličine je oko 106 [m/s]), hidrogeološki je kolektor, a karakterizira je pukotinski sustav koji lako prima i transmitira vodu. Vodonosnik je pukotinskog tipa, bez vodnog lica, a nivo podzemne vode u budućim bušotinama očekuje se na minimalnoj koti između $\pm 0,00 \mathrm{~m} \mathrm{n}$.m. i $+1,00 \mathrm{~m} \mathrm{n} \cdot \mathrm{m}^{13}$.

Na lokaciji zahvata provedeni su pedološki istražni radovi prema kojima je istraživani prostor slabo i umjereno pogodan za izgradnju golf-terena. Snimljeno je više od 40 stabala koja su svrstana u tri kategorije s obzirom na dimenzije, starost, vitalnost, oblik i oštećenost krošnje. Na temelju tih podataka u prvoj je fazi izlučeno 26 stabala, a nakon detaljnog pregleda izvedbenog projekta četiri su stabla uklonjena. Također, prilikom obilaska terena utvrđene su granice šumske vegetacije i neobraslih (pašnjačkih) površina koja moraju biti predmet botaničkog pregleda ${ }^{13}$.

Ključni je problem svakog golf-terena osiguravanje dovoljne količine vode za navodnjavanje terena. Analiza potrebnih mjerodavnih količina vode za piće, sanitarne potrebe, kao i vode za zalijevanje zelenih površina (golfigrališta) te ocjena mjerodavnih količina sanitarnih i oborinskih otpadnih voda predstavlja važan segment pri procjeni utjecaja planiranih zahvata na okoliš.

Vransko jezero najveće je prirodno jezero u Hrvatskoj. Riječ je o kriptodepresiji u kršu koja je ispunjena blago zaslanjenom vodom. Površina je jezera dva metra iznad površine mora, dok je dno četiri metra ispod razine

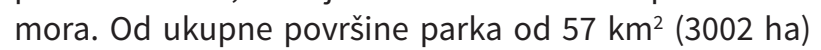
samo jezero zauzima oko $30,16 \mathrm{~km}^{2}$. Pruža se u smjeru sjeverozapad-jugoistok i duljine je oko $13,6 \mathrm{~km}$ te širine između 1,4 i 3,4 km. Sjeverni dio jezera nešto je dublji od južnog, a dubina varira između 2 i 5 m. Nalazi se kraj Pakoštana, uz obalu Jadranskog mora od kojeg je odijeljeno vapnenačkim grebenom širine od 800 do 2500 metara. Zbog blizine mora i dna koje je niže od površine mora slana morska voda prodire u jezero podze- 
mno kroz greben i kroz kanal Prosika te ga čini bočatim. Jezero ima promjenjiv vodostaj s varijacijama od jedan do dva metra. Najviši je vodostaj u proljeće, a najniži tijekom velikih ljetnih suša ${ }^{16}$.

Vransko jezero najniža je točka Ravnokotarske ploče i prikuplja gotovo polovinu površinskih voda Ravnih kotara. Najveći prinos slatke vode u Vransko jezero ima povremeni vodotok Kotarka koji prikuplja vode glavnih sabirnih kanala (Borelovice, Lamešca, Vrbice i Jablanca). Pritoka je jezera i Lateralni kanal koji prikuplja oborinske i izvorske vode sa sjeveroistoka te brojni izvori. Zbog plitkoće, voda u jezeru podložna je naglim promjenama temperature. One se kreću od $2,9^{\circ} \mathrm{C}$ tijekom veljače do $25,2{ }^{\circ} \mathrm{C}$ tijekom srpnja. Zimi povremeno dolazi do zamrzavanja površine jezera. Voda u jezeru saliniteta je 0,16 do 0,86 promila. Za vrijeme suša i niskih vodostaja tijekom ljeta voda u jezeru nešto je slanija nego u ostatku godine. Istraživanja su pokazala da je kvaliteta i čistoća vode degradirana u posljednjih nekoliko desetljeća. Opasnost od iscrpljivanja ograničenih rezervoara pitke vode za potrebe golf-kompleksa tim je veća ako se podsjeti da je tijekom 2012. godine i velike suše vodostaj jezera dulje od 17 mjeseci bio niži od pola metra. Slanost i temperatura vode bili su veći nego ikad, jer se salinitet jezera opasno približio vrijednostima Jadranskog mora (oko 38 promila). Uzrok je tako niskog vodostaja i visokog saliniteta kanal između mora i jezera koji je prokopan 1770. kako bi se isušilo močvarno tlo i dobilo obradivo zemljište. Sada taj kanal predstavlja problem jer preko njega nadire previše morske vode. Ugrožen je bio cijeli ekosustav Parka prirode i Ornitološkog rezervata. Zbog niskog vodostaja tršćak je bio suh i čaplje dangube i mali vranci uopće se nisu gnijezdili, a u samom je jezeru pomrla gotovo tona ribe ${ }^{16}$.

Količine vode potrebne za navodnjavanje zelenih površina ovog golf-igrališta dijele se na potrebe navodnjavanja sljedećih segmenata: fairwaya ukupne površine 14,8 ha, primarnih roughova ukupne površine 26,6 ha te greenova i teejeva - ukupna površina $2,8 \mathrm{ha}^{13}$.

Nedostatak vode vezane uz padaline trebao bi se pokriti iz drugih izvora, među kojima se kroz projekt pretpostavlja korištenje raspoloživim volumenom vode iz pet umjetno oblikovanih jezera, koja su predviđena na ukupnoj površini od 2,02 ha (jezero $1-0,51$ ha, jezero 2 - 0,35 ha, jezero $3-0,27$ ha, jezero $4-0,58$ ha i jezero $5-0,31 \mathrm{ha})^{13}$.

Jezero 1 bilo bi smješteno uz golf-igralište 18 , s njegove sjeverne strane. Jezero 2 bilo bi smješteno uz golfigralište 10 , s njegove južne strane, dok bi Jezero 3 bilo smješteno uz golf-igralište 7 , s njegove istočne strane. Jezera 4 i 5 bila bi smještena uz golf-igralište s dodatnih devet rupa. Jezera 1, 2, 4 i 5 bila bi povezana gravitacijskim otvorenim kanalom, u cilju osiguranja optimalne raspodjele vode i njezine kasnije upotrebe ${ }^{13}$.

Potrebni kapacitet crpne stanice, odnosno kapacitet tlačnog sustava izvorišta podzemne vode, odredio bi se u odnosu na potrebe za vodom i dinamiku punjenja i pražnjenja jezera. Pri tom bi bilo potrebno voditi računa da razina vode $u$ jezeru ni u jednom trenutku ne padne ispod biološkog minimuma, odnosno $2,5 \mathrm{~m}^{13}$.

Količina vode koja je potrebna za zalijevanje travnatih površina golf-centra, prema mišljenju tijela koja su provela studiju utjecaja na okoliš, navodno bi bila dohvatljiva crpljenjem iz više bušotina opremljenih odgovarajućom opremom i pumpama. Podloga je za prethodnu tvrdnju probno višednevno pumpanje iz četiri probušene bušotine kojim se nije snizio nivo podzemne vode u bušotinama i okolnim kanalima. Za određivanje broja bušotina i njihove dubine preporučeno je obaviti geofizičke istražne radove prikladnom metodom, čime bi se odredila područja veće ili manje zasićenosti vodom, a tako i mjesta bušenja i zahvata vode iz bušotina. Međutim, Studija utjecaja na okoliš ne uzima u obzir dvije važne činjenice: probno crpljenje vršeno je u zimi, dakle u vlažnom dijelu godine, a ne tijekom sušnih razdoblja, kao i činjenicu da se prostornim razvojnim planovima u uskom krugu planirana izgradnja još četiri golf-terena koji se oslanjaju na iste podzemne izvore vode, što je definitivno važan podatak koji je (ne)namjerno propušten u studiji.

U rješenju kojim MZOPUG odlučuje da je golf-teren uz sam Park prirode prihvatljiv za prirodu stoji da količine vode koje će se crpiti za golf nisu nikakva opasnost za Vransko jezero. Izrađivači SUO-a tvrde da će za navodnjavanje trebati $476025 \mathrm{~m}^{3}$ vode godišnje ${ }^{13}$. Kad je isti tim radio studiju za golf-igralište „Fratarska šuma” u Istri, procijenio je da tamo za navodnjavanje treba, projicirano na veličinu Baštijunskog briga, $667950 \mathrm{~m}^{3}$ godišnje, dakle 40 posto više nego na Vranskom jezeru, i to u sušnijem podneblju nego što je Istarsko. Studija utjecaja na okoliš, unatoč ograničenim istraživanjima, ostavlja usprkos svemu mogućnost da je uvažavajući geološke osobitosti i laboratorijske rezultate moguće povećanje zaslanjenja nakon dugotrajne eksploatacije bušotina crpljenjem vode. Također, u Studiji je naznačeno da su rezultati dobiveni laboratorijskim ispitivanjima vode svrstali vodu u skupinu slanih voda, pri čemu se slana voda može rabiti za zalijevanje, ali uz potrebu za naknadnim ispiranjem tla u cilju sprječavanja nagomilavanja soli u tlu. 
U sklopu ocjene utjecaja zahvata na okoliš analizirani su utjecaji tijekom pripreme i građenja zahvata te utjecaji tijekom korištenja zahvata. Analiziran je utjecaj na 12 sastavnica okoliša tijekom pripreme i građenja, i to utjecaj na stanovništvo, floru, faunu, područje ekološke mreže, tlo, vode, zrak, kulturno-povijesnu baštinu, krajobraz, utjecaj buke i otpada. Tijekom građenja zahvata očekuje se javljanje utjecaja na sastavnice okoliša i na društvenu zajednicu koji su posljedica uobičajenih građevinskih aktivnosti, ali se za njih ocjenjuje da su privremenog karaktera i nestaju nakon prestanka građevinskih aktivnosti ${ }^{13}$.

Prema SUO-u, nijedna analizirana sastavnica okoliša nije dobila numeričku vrijednost utjecaja veću od 25 - za krajobraz (od maksimalne vrijednosti 125). Sve numeričke vrijednosti bile su u granicama definicije kod koje je utjecaj zanemariv. Ovako niske numeričke vrijednosti rezultat su, prema mišljenju autora Studije, postojećeg stanja okoliša koji je trenutačno u znatnoj mjeri devastiran i u lošem stanju. Postojeće odlagalište i nekontrolirano bacanje otpada po površini većeg dijela lokacije zahvata pridonijele su ovakvim rezultatima analize ${ }^{13}$.

Prema SUO-u, vrlo slaba kvaliteta tla i postojeći devastirani biljni pokrov također su utjecali na rezultate analize utjecaja tijekom pripreme i građenja. Generalno gledano, sveukupne aktivnosti koje se planiraju provoditi tijekom pripreme i građenja zahvata mogu se okarakterizirati kao količine i/ili kvalitativne promjene komponenata okoliša koje, prema autorima Studije, nemaju znatan utjecaj na sastavnice okoliša. U okviru analize utjecaja na okoliš tijekom pripreme i građenja, sanacija i zatvaranje postojećeg odlagališta koja bi se trebala odvijati paralelno s izgradnjom zahvata ocijenjena je kao pozitivan utjecaj na sastavnicu okoliša zrak ${ }^{13}$.

Međutim, propušteno je napomenuti da sanaciju odlagališta ne financira investitor golf-terena, već da sanaciju odlagališta koje je stajalo nesanirano više od 50 godina provodi država o trošku poreznih obveznika u iznosu većem od 30 milijuna kuna, a sanirano zemljište bit će predano privatnom investitoru na uporabu, što je važan prigovor ekoloških grupa.

Na ukupno 11 sastavnica okoliša analizirani su utjecaji tijekom korištenja zahvata, a to su utjecaj na stanovništvo, floru i faunu, područje ekološke mreže, tlo, vode, zrak, kulturno-povijesnu baštinu, utjecaj na krajobraz, buku, otpad i prirodne resurse. Od analiziranih sastavnica, autori Studije jedino su za sastavnicu vode (crpljenje podzemne vode) i sastavnicu prirodni resursi (ista kategorija) ocijenili utjecaje kao prihvatljive s negativ- nom numeričkom vrijednošću od 40 (crpljenje podzemne vode) i 30 (prirodni resursi - vodni resurs) od ukupne moguće vrijednosti $125^{13}$.

Planirani način gradnje, primjena najnovijih spoznaja i tehnoloških rješenja, unaprjeđenje stanja prostora u odnosu na postojeće stanje i postojeće aktivnosti u širem krugu lokacije zahvata (poljoprivreda i turizam) pridonijele su ovakvim rezultatima analize mogućih utjecaja na sastavnice okoliša. Ostaje upitna utemeljenost paralela s poljoprivrednom proizvodnjom, koje zbog izloženosti buri i smeću s nesaniranog deponija na ispitivanom području zapravo i nema.

S obzirom na blizinu PP-a Vransko jezero, provedeno je i istraživanje mogućih negativnih utjecaja na ptice močvarice Vranskog jezera i okolnih područja Nacionalne ekološke mreže. Golf-teren nalazi se u neposrednoj okolici dvaju područja (Jasen i Jezerine) koja nisu u sastavu Parka prirode, ali su u sastavu Nacionale ekološke mreže i važni su kao hranilište za više vrsta močvarica, a u prvoj Studiji utjecaja na okoliš nije bio uključen ornitolog, već je naknadno nakon prigovora zainteresirane stručne javnosti angažiran ornitolog s izdvojenim mišljenjem koje nije i jedinstveno mišljenje struke ${ }^{17}$.

Mišljenje naknadno angažiranog ornitologa iznosi procjenu da kopneno stanište Baštijunski Brig nema važnosti za faunu ptica močvarica Vranskog jezera ${ }^{17}$.

Zbog neposredne blizine močvarnim staništima četiri su potencijalna negativna utjecaja budućeg terena za golf: zagađenje jezerskog ekosustava pesticidima i umjetnim gnojivom s golf-terena, smanjenje dotoka vode u jezero, povećanje zagađenja bukom, noćnim svjetlom i fizičkim uznemiravanjem ptica te nestanak hranilišta ptica močvarica. Mogući negativni efekt u Mišljenju opisan je jedino kod treće moguće točke utjecaja - povećanja zagađenja bukom, noćnim svjetlom i fizičkim uznemiravanjem ptica. Budući da se golf-teren nalazi u neposrednoj okolici dvaju područja (Jasen i Jezerine) koja nisu u sastavu Parka prirode, ali su u sastavu Nacionale ekološke mreže i važni su kao hranilište za više vrsta močvarica, a postoji realna opasnost povećanje uznemiravanja ptica ulaskom ljudi (korisnika golf-terena) ili pasa, bukom ili noćnim svjetlom ${ }^{17}$.

Kao kompromisno rješenje predlaže se osigurati zaštitnu mjeru fizičkog ograđivanja golf-igrališta od Jasena i Jezerina tako da ljudi ili psi ne mogu prijeći ogradu, a uz ogradu treba postaviti, ako su potrebni, bukobrane i zaštitu od noćnog svjetla. U konačnici, s golf-terena u područja Jasen i Jezerine ne smiju dolaziti ljudi, buka ni noćno svjetlo, kao ni umjetna gnojiva i pesticidi. Studi- 
ja, međutim, ne daje detaljan uvid u obveze RH prema području koje je uključeno u mrežu Natura 2000 i ne daje jasan uvid u činjenicu da je golf-teren planiran samo 100 m od granica PP-a Vransko jezero ${ }^{17}$.

lako sama sanacija odlagališta nema veze s projektom izgradnje golf-terena, Studija naglašava pozitivne strane sanacije odlagališta kroz mišljenje da veliki broj galebova i vrana ima znatan negativni utjecaj na ornitofaunu cijelog jezera putem izravne kompeticije za hranu, putem direktnog i intenzivnog uznemiravanja drugih vrsta ptica, putem hranjenja jajima i ptićima drugih vrsta ptica, putem kompeticije na noćilištu u velikom tršćaku ornitološkog rezervata itd. Isto je neosporno, upitno je može li se sanacijom odlagališta opravdavati izgradnja golf-terena, posebice s obzirom na činjenicu da sanaciju provodi država javnim novcem ${ }^{13}$.

S obzirom na zakonske odredbe i blizinu zaštićenih područja, izrađena je Studija utjecaja na okoliš i investitor je nakon provedene analize dobio pozitivnu ocjenu izvođača Studije, pri čemu je ocijenjeno da je zahvat izgradnje i korištenja golf-igrališta „Baštijunski brig”, Biograd na Moru, prihvatljiv za okoliš uz primjenu mjera zaštite okoliša i programa praćenja stanja okoliša.

Međutim, ostaje važno napomenuti da izvođača Studije bira i plaća investitor i nedvojbeno su izvođači pod snažnim utjecajem investitora. U javnosti su ekološke udruge snažno otvarale problem mogućeg zaslanjivanja podzemnih rezervoara pitke vode, upitne kvalitete izrade Studije te mogućeg sukoba interesa na više razina između izvođača Studije i nadležnog državnog tijela koje Studiju prihvaća, uz moguće postojanje pogodovanja investitorima te neuzimanje u obzir činjenica da se prema Prostornom planu Zadarske županije, osim na Baštijunskom brigu, tereni za golf mogu graditi na Bokanjcu, Tustici, Vrani, Ninskim Stanovima, Šepurinama kod Zatona, Ladini kod Novigrada, Miranjama Donjim kod Benkovca i Županima kod Obrovca, što otvara mogućnost kumulativnog efekta ${ }^{18}$.

No osim prihvaćene Studije utjecaja na okolišris, o projektu je Mišljenje donijela i Uprava za zaštitu prirode Ministarstva kulture nakon što je Državni zavod za zaštitu prirode donio svoje Mišljenje (klasa 612-07/10-29/12, 2. veljače 2010.) u kojem smatra da se planirani zahvat nalazi unutar područja ekološke mreže HR1000024 Ravni kotari kao međunarodnog važnog područja za ptice te neposredno u blizini još jednog važnog područja za ptice HR1000025 Vransko jezero i Jasen te područja važnog za divlje svojte i stanišne tipove HR2000914 Ornitološki rezervat Vransko jezero i Jasen ${ }^{19}$.
Nadalje, utjecaji planiranog zahvata na područje ekološke mreže Ravni kotari mogu se očitovati u gubitku staništa, manjim dijelom (10 \%) izgradnjom smještajnih kapaciteta, a većim dijelom uslijed zamjene autohtone vegetacije neautohtonom travnatom površinom. Istaknuto je da se uslijed primjene velike količine pesticida i gnojiva potrebnih za održavanje golf-terena očekuje ispiranje voda s golf-terena na područja ekološke mreže HR1000025 i HR2000914, što bi moglo dovesti do promjena kvalitete vode u Vranskom jezeru i time utjecaja na staništa biljaka i ostale organizme. Konačno, tijekom izgradnje golf-terena moglo bi doći do ispiranja zemlje u Vransko jezero te do uznemiravanja ptica na području samog zahvata te, s obzirom na malu udaljenost zahvata od jezera, onih ptica koje dolaze na područje Vranskog jezera. Zaključno, izneseno je da se uz istočnu granicu golf-igrališta nalazi prostor također namijenjen igralištu za golf koji zajedno s tri druga golf-terena predviđena Prostornim planom Zadarske županije predstavlja kumulativni utjecaj na navedena područja ekološke mreže napose izgradnjom smještajnih kapaciteta, što za sobom može povlačiti dodatnu znatnu potrošnju vode i neizbježno uznemiravanje ptica. Na temelju navedenog, zaključeno je da nije moguće isključiti negativne utjecaje predmetnog zahvata na ciljeve očuvanja i cjelovitosti područja ekološke mreže ${ }^{19}$.

Upravo očuvanje jedinstvenoga ornitološkog rezervata kao dijela PP-a Vransko jezero od mogućega štetnog utjecaja izgradnje golf-terena prioritetan je zadak i stručne i šire javnosti, budući da Ornitološki rezervat koji je proglašen 1983. spada među najvrjednija ornitološka područja u Hrvatskoj. Sjeverozapadni je dio jezera 1983. godine proglašen posebnim ornitološkim rezervatom i uvršten u popis važnih ornitoloških područja u Europi. Park prirode 2013. godine uvršten je u popis zaštićenih močvarnih područja Ramsarskom konvencijom koja obvezuje RH na obazrivo postupanje ${ }^{20}$.

Sve navedeno važno je prilikom donošenja konačne odluke o prihvatljivosti zahvata izgradnje i korištenja golf-igrališta „Baštijunski brig” za okoliš, uvažavajući i obveze Hrvatske povezane s mrežom NATURA 2000 i Ramsarskom konvencijom, kao i temeljni cilj razvoja održivi razvoj. Problemi koji se javljaju s održivim razvojem golfa u svijetu i velik pritisak na okoliš takvu odluku čine još važnijom. Hrvatska je još uvijek nedovoljno turistički izgrađena i ima relativno nezagađen okoliš. Neizgrađenost podrazumijeva nedostatak infrastrukture koja je nužna za elitni turizam, a ta činjenica istodobno predstavlja i prednost, jer još uvijek ima dovoljno prostora koji nije popunjen hotelskim objektima niže kva- 
litete namijenjenima masovnom turizmu, a uz dobru bi se razvojnu strategiju mogao pretvoriti u elitnu destinaciju, pri čemu postoje i alternativna rješenja u odnosu na ekološki upitan golf-turizam - ekoturizam, vinski turizam, industrijska baština iskorištena u turističke svrhe, kulturni turizam, wellness i zdravstveni turizam i sl. Kod utvrđivanja vizije i strategije razvoja i podizanja kvalitete destinacije svi dionici moraju biti aktivno uključeni u definiranje modela budućega razvoja kojim se treba očuvati ono što imamo, ali moramo uvijek imati u vidu i činjenicu da potencijalni investitor koji je spreman uložiti svoja financijska sredstva želi ostvariti i višak vrijednosti, odnosno imati rentabilno poslovanje, pri čemu je profit i održivost investicije investitoru iznad održivog razvoja. Izgradnja svih vrsta kapaciteta i stopa porasta broja ležaja u destinaciji treba maksimalno štititi prostor i prirodu kao dugoročni temeljni preduvjet interesa razvoja turizma.

Budući ciljevi razvoja trebaju biti mjerljivi, jasni, transparentni i ostvarivi, usmjereni na razvoj temeljen na načelima održivosti, odnosno održivi razvoj kao koncepciju koja osigurava dugoročni boljitak lokalnom stanovništvu i zajednici s jedne strane te zadovoljstvo turista kao korisnika proizvoda i/ili usluge s druge strane. Kvalitativna načela razvoja moraju se uvažavati jednakovrijedno kao i kvantitativna jer svako odstupanje od takvog razumijevanja međuovisnosti kvantitete i kvalitete najozbiljnije prijeti daljnjem dugoročnom razvoju turističke privrede, kao i održivom razvoju u cjelini.

\section{Rasprava rezultata}

\subsection{Važnost područja Parka prirode Vransko jezero i Ornitološkog rezervata}

Važnost područja Parka prirode Vransko jezero u neposrednoj blizini grada Biograda na Moru pruža iznimnu komparativnu prednost ovoj destinaciji u odnosu na brojne druge destinacije na obali. Upravo PP Vransko jezero predstavlja jedinstveno obalno slatkovodno jezero s vrijednim močvarnim i poplavnim staništem te je od iznimne važnosti za zaštitu ptica i očuvanje bioraznolikosti. To je prostor velike prirodne i krajobrazne ljepote te bogate kulturno-povijesne baštine koji lokalnom stanovništvu omogućuje kvalitetan život i razvoj u skladu s prirodom, a posjetiteljima priliku za nove spoznaje i nadahnjujuće iskustvo. Vransko jezero najveće je jezero u Hrvatskoj i jedno od samo dva velika močvarna područja u sredozemnom dijelu Hrvatske. Područje Parka prirode Vransko jezero, zajedno sa susjednim poplavnim područjem Jasen, jedinstveni je prirodni i hidrogeološki fenomen ${ }^{20}$.

Iznimna geološka aktivnost u prošlosti stvorila je raznolikost kopnenih oblika i geokemijskog sastava stijena na malom području, što za posljedicu ima različite tipove tla koji podržavaju brojna staništa i vrste. Područje Vranskog jezera i Jasena, uz deltu rijeke Neretve, Lonjsko polje i Kopački rit, jedno je od najvrjednijih močvarnih staništa u Hrvatskoj. To je posljednje gnjezdilište nekoliko vrsta čaplji u hrvatskom priobalju te važno zimovalište mnogih vrsta vodarica na europskoj razini. Jezero se nalazi na sjecištu međukontinentalnih selidbenih putova te je stoga nezamjenjivo odmorište velikog broja migratornih vrsta koje iz sjeverne Europe ili zapadnog Sibira putuju prema svojim zimovalištima. U razdoblju najintenzivnije selidbe u Parku prirode može se nalaziti između 800000 i 1000000 ptica istovremeno, a više od 200000 ptica redovito se koristi Vranskim jezerom kao zimovalištem ${ }^{20}$. Velika je prirodna vrijednost Parka prirode zajednica slatkovodnih i močvarnih ekosustava, posebice u području poplavnih livada i tršćaka. Bogatstvo flore i riblje faune (autohtone i unesene), zajedno s rezervoarom slatke vode, dodatno povećavaju ekološki značaj ovog područja. Vransko jezero prvi je put zaštićeno 1983. godine, proglašenjem posebnog ornitološkog rezervata u sjevernom dijelu jezera. Sam Park prirode formalno je proglašen 1999. godine na području od $57 \mathrm{~km}^{2}$ (od čega $30 \mathrm{~km}^{2}$ iznosi površina samog jezera). Površinom od $8,65 \mathrm{~km}^{2}$ ornitološki rezervat zauzima sjeverozapadni dio Vranskog jezera do granice Parka prirode. Ovo malo močvarno područje ostatak je nekadašnjeg deseterostruko većeg Vranskog blata, močvare koja je melioracijskim kanalima i probijanjem kanala Prosika na jugoistočnoj obali jezera tijekom 18. stoljeća gotovo potpuno isušena i dovedena na rub opstanka, a s njom i živi svijet koji je o njoj ovisio ${ }^{16}$.

\subsection{Kritične točke razvoja golf-turizma na području grada Biograda na Moru}

\subsubsection{Utjecaj izgradnje golf-terena i popratnih sadržaja u golf-industriji na prostor i krajobraz}

Budući da se golf igra u prirodi, neizbježan je njegov utjecaj na stanje okoliša, od oblikovanja i izgradnje do održavanja i vođenja. Upravo su osobite značajke golfa 
oblikovanje igrališta strukturama krajobraza. Izgradnja golf-terena direktno mijenja najmanje stotinjak hektara prostora njegovim privođenjem drugoj namjeni, a ukupno cijeli kompleksi s pratećim sadržajem i potrebnom infrastrukturom unose promjene na više stotina hektara prostora.

Igrališta za golf mogu se graditi na kopnu, otocima, na obali i u unutrašnjosti, na brdima sjevera i pustinjama juga, u metropolama i malim turističkim mjestima. Kad je god moguće, ovisno o zamisli arhitekta, pokušava se minimalizirati šteta u krajobrazu, ali neizbježna je krajobrazna agresija kojom se trajno, više ili manje, narušava postojeća vegetacija i oblik krajobraza. Gledano s bioetičkog stajališta. na taj se način nepotrebno i negativno utječe na ukupnu biološku i krajobraznu raznolikost, čime se umanjuje vrijednost prostora. Naime, dolazi do gubitka staništa i vrsta, fragmentacije staništa i degradacije krajobraza, a moguće je i oštećenje kulturno-povijesne baštine.

Neovisno o veličini iskorištenog prostora, prilikom faze izgradnje odnosno ravnanja golf-terena doprema se i upotrebljava teška mehanizacija, nakon čega krajolik biva nereverzibilno izmijenjen.

Prilikom izbora lokacije postoje preporuke urbanista koje je prostore moguće koristiti za izgradnju golf-terena, a koje treba izbjegavati.

Na popisu su lokacija koje se ne mogu koristiti za izgradnju golf-terena zaštićena područja i nacionalni parkovi te određena staništa koja treba zaštititi, zaštićene šume osobitog značaja, šume za zaštitu od lavina, šume-izletišta i rezervati, prirodne šume, kao i šume u gusto naseljenim područjima te područja s osobitim kulturnopovijesnim, geološkim i geomorfološkim značenjem ${ }^{8}$.

Kao urbanistima potencijalno prihvatljive zone u obzir dolaze područja zaštićenih krajolika i slični dijelovi prirodnih parkova, ako definirane zaštitne svrhe nisu ugrožene, odnosno ako je planirano zemljište za golf pristupačno javnom izletničkom prometu i ako se nakon preoblikovanja harmonično uklapa u tipičan izgled krajolika i ne ugrožava prirodne sposobnosti područja; spomenici prirode, ako se mogu integrirati u golf-igrališta bez oštećenja; ekološki vrijedna i neopterećena područja, ako se mogu integrirati u igralište bez eventualnog oštećenja; krajolici bogatih struktura i vrsta, ako se mogu očuvati i osigurati strukture tipične za krajolik i potencijal vrsta; područja sa zaštićenim dijelovima krajolika, ako nisu ugrožena planiranjem golf-igrališta; poznata turistička područja i prioritetna područja za odmor, ako je zajamčen pristup svima; područja zašti- ćenih voda, zone II. i III., uz poštivanje odgovarajućih obveza te šumska područja bez osobitog značenja ${ }^{8}$.

Važno je prilikom izbora lokacije voditi računa o nizu faktora kako bi se smanjila moguća šteta. To posebno vrijedi za golf-terene $u$ blizini arheoloških nalazišta i nalaza koji predstavljaju tek djelić onoga što se nalazi na određenom području. U mnogim golf-igralištima postoje nalazi povijesne važnosti. U više je navrata potrebno izvršiti povijesno-arheološko razmatranje kako bi se utvrdio točan obuhvat i narav arheoloških nalazišta te povijesna otkrića povezana s tim područjem. Na temelju tih važnih informacija moguće je zatim izmijeniti model upravljanja ili projekt izgradnje golf-igrališta. Čak i ispod zemlje, arheološki se nalazi mogu oštetiti prolaskom teških strojeva, zemljanim radovima ili sadnjom biljaka.

Važno je izbjegavati nepotrebne zahvate u postojeće visokovrijedne strukture staništa, npr. u vlažna područja, prirodne vode, u suhe i siromašne površine, kao i krčenje šuma i polja i nasipa obraslih grmljem, pojedinih stabala ili skupina stabala ${ }^{8}$.

Mali prolazi u grmlju ili nizovima drveća iznimno su dopušteni ako se zemljište inače ne bi moglo povezati za igru i ako se posljedice tog zahvata mogu ispraviti na lokaciji. lako je dozvoljeno korištenje šumskih površina u slučaju šume bez posebnog značenja ili svrhe, i to bi trebalo maksimalno izbjegavati. Na rubovima ili između staza treba stvarati mirne ekološki zaštićene zone, gdje se ne igra i gdje nema strojeva za održavanje igrališta, koje mogu poslužiti kao zaštitne zone za razne vrste životinja. Te zone treba međusobno povezati i sa staništima na rubu zemljišta gustom mrežom ekstenzivno održavanih livada i stabala, kao i vodenih površina ${ }^{8}$.

Oblikovanje golf-igrališta treba prilagoditi tipičnim odlikama regionalnog ili za lokaciju specifičnoga kultiviranog krajolika te ga najbolje održavanjem struktura staništa i postojećeg reljefa staništa uključiti u izgled krajolika8

Nanošenje i odnošenje tla uz najbolju prilagodbu staza u postojećem reljefu treba biti ograničeno na najmanju moguću mjeru potrebnu za igru. $U$ pravilu, potrebno je izvršiti u okviru +/-2,00 m ispod/iznad postojeće površine zemljišta. Kod neizbježnih terasiranja na dijelovima zemljišta koji su prestrmi za igru (više od $12 \%$ ) treba oblikovati blage nagibe i izbočenja, po izgledu bliske prirodnima. Umjetne objekte koji se ne uklapaju u krajolik treba izbjegavati ${ }^{8}$.

S obzirom na to da namještaj, zgrade i staze duž igrališta mogu biti previše uočljive, stvarajući dojam umjetnog okruženja, trebalo bi uvijek upotrebljavati mate- 
rijale i prirodne boje koje se stapaju s okolinom, a na otvorenim dijelovima postaviti oznake, kante, uređaje za pranje loptica i drugo tako da nisu vidljivi na obzoru te da ne priječe pogled u daljinu .

Osim redovite drenaže na završnim i početnim poljima i bunkerima koji čine samo 3 do $5 \%$ površine, trebalo bi na ostalom dijelu zemljišta odustati od drenaže, osim možda s iznimkom područja za igru gdje postoji opasnost od stajaće vode. Drenaža ekološki visoko vrijednih vlažnih staništa ionako nije dozvoljena ${ }^{8}$.

Nove umjetne ribnjake treba prirodno oblikovati, no ukrasna jezerca koja djeluju umjetno najčešće nisu potrebna. Po mogućnosti, trebalo bi osigurati da samo manji dijelovi obala graniče sa stazama za igru, kako bi se preostale površine obale mogle razvijati kao prirodna staništa. Vodene površine koje su ekološka ravnoteža samo malim dijelom mogu smanjiti golf-staze ${ }^{8}$.

Za bolje povezivanje igrališta s krajolikom i za povećanje raznolikosti vrsta tipičnih za krajolik u načelu treba upotrebljavati domaće nasade koji odgovaraju lokaciji. Pri odabiru stabala, grmlja, cvijeća i livadnih esencija važno je da budu što više u skladu s postojećom vegetacijom, preferirajući autohtone vrste i u prvom redu one koje spontano rastu u okruženju. Za pijesak u bunkerima poželjno je odabrati takvu vrstu pijeska koja nije u izrazitoj suprotnosti s prirodnom bojom terena8.

Sve staze za pješačenje koje prolaze zemljištem ili njegovim rubom treba zadržati, ako treba i premještanjem pojedinih dijelova staza kako ne bi dolazilo do ometanja igre. To ne vrijedi za staze koje se upotrebljavaju u poljoprivredne i gospodarske svrhe. Pri smještaju golfigrališta u vrlo posjećene izletničke regije trebalo bi osigurati dodatne staze za pješačenje ${ }^{8}$.

Ograđivanje golf-zemljišta treba u načelu izbjegavati. Jedino na područjima gdje se može računati sa štetama od zečeva ili divljih svinja odgovarajuće ograđivanje dolazi u obzir. Privremene iznimke čine i zaštitne ograde za nove nasade.

\subsubsection{Ekološki aspekt korištenja vodenim resursima za vodoopskrbu i navodnjavanje golf-terena}

Prilikom održavanja izgrađenog golf-igrališta, osim utjecaja na krajobraz, multipliciraju se i drugi negativni utjecaji na okoliš.

Prvenstveno treba istaknuti izrazito negativan utjecaj na vodoopskrbu. Voda na igralištu upotrebljava se za sanitarno-potrošne namjene, a drugi, znatniji dio za zalijevanje. Godišnja potrošnja vode za zalijevanje travnjaka ovisi o klimatskim uvjetima (temperaturi, vlazi, vjetru, padalinama, izloženosti), morfologiji i strukturi tla, vrsti travnjaka, načinu upravljanja travnatim površinama, pritisku prometa i rasponu zalijevanih površina ${ }^{21}$.

Posebno intenzivno zalijevanje vrši se na početnim i završnim područjima igrališta, uključivši i rubna područja, površinama staza (posebno mjesta očekivanog doleta loptice) te rubna područja staza. Ostala područja igrališta uglavnom se ne zalijevaju, već se prepuštaju prirodnom režimu navodnjavanja. Kako bi se smanjila potrošnja vode za zalijevanje, sve veća pažnja usmjerava se na selekciju trava, predstavnika autohtone flore ili na izbor suši otpornijih varijeteta, a također se povećava pažnja o kvaliteti tla tj. supstrata?

Međutim, usprkos svim naporima za minimalizaciju količina utrošene vode, prema standardima WWF-a, Svjetskog fonda za zaštitu prirode, za navodnjavanje golf-terena troši se 6500 do $10000 \mathrm{~m}^{3} /$ ha godišnje. Znajući da golf-tereni obuhvaćaju 80 do 150 ha, aproksimativno se dolazi do potrošnje od oko $1000000 \mathrm{~m}^{3}$ po igralištu godišnje, što odgovara potrošnji grada od 12000 stanovnika, što je prema nekim autorima tri do četiri puta više od prosječnih potreba za vodom u poljoprivredi ${ }^{22}$.

$\mathrm{S}$ bioetičkog stajališta javljaju se i etički konflikti, budući da se na iskorištenom zemljištu ne proizvodi hrana, već se tlo i voda troše u sportske svrhe, a u obalnim je zonama dodatni problem mogućnost zaslanjivanja podzemnih voda zbog prekomjernog crpljenja.

Godišnje se za tretman dijelova igrališta po hektaru utroši oko $400 \mathrm{~kg} \mathrm{~N}$, oko $200 \mathrm{~kg} \mathrm{P}_{2} \mathrm{O}_{5}$ te oko $300 \mathrm{~kg} \mathrm{~K}_{2} \mathrm{O}$. Uz gnojiva se apliciraju i velike količine sredstava za zaštitu bilja koja također mogu onečistiti obližnje vode (podzemne i/ili nadzemne) ${ }^{23}$.

Godišnja potrošnja vode za zalijevanje golf-igrališta na terenima od 18 rupa kod kojih su fairwayi prekriveni puzećom rosuljom (Agrostis stolonifera) iznosi 200000 do $225000 \mathrm{~m}^{3}$. Kod terena sa 18 rupa s fairwayima prekrivenima s više vrsta trava, npr. engleskim ljuljem (Lolium perenne), livadnom vlasnjačom (Poa pratensis) i crvenom vlasuljom (Festuca rubra), iznosi manje, odnosno 60000 do $170000 \mathrm{~m}^{3}$, što je još manje nego kod terena sa 18 rupa prekrivenim travom za toplu sezonu (npr. bermudska trava), gdje je potrošnja između 100000 i $200000 \mathrm{~m}^{3} .{ }^{21}$

Primjerice, u Kaliforniji jedno golf-igralište od 18 rupa troši i $3000 \mathrm{~m}^{3}$ vode dnevno (dovoljno za osobnu upo- 
trebu oko 15000 stanovnika) te čak do dvije tone kemijskih gnojiva, herbicida i pesticida godišnje. Brojne studije potvrđuju zagađenje podzemne i pitke vode pesticidima koje je moguće povezati s primjenom na golfterenima ${ }^{24,25}$.

U golf-destinacijama na Malajskom poluotoku, Polineziji i Filipinima zbog klimatskih uvjeta jedno golf-igralište od 18 rupa dnevno troši po 5000 prostornih metara vode, što je dovoljno za oko 60000 tamošnjih seoskih stanovnika, a upotreba kemikalija po igralištu iznosi i do četiri tone godišnje ${ }^{26}$. Važno je razvoj golf-igrališta promatrati i kroz podatak da je zbog pomanjkanja vode za navodnjavanje i zagađenih okolnih zemljišta krajem osamdesetih godina upravo u jugoistočnoj Aziji došlo do masovne gladi i migracije seljaštva u gradska područja.

Kao jedno od alternativnih rješenja koja mogu smanjiti, iako ne i otkloniti potrebu za trošenjem vode u svrhu navodnjavanja, ističe se primjena senzora za detekciju vlažnosti tla koji se ugrađuju ispod površine terena koji se navodnjava prema potrebama, a ne vremenskim ritmom rada sustava za navodnjavanje ${ }^{27}$. Dio vode za navodnjavanje moguće je dobiti reciklažom otpadnih voda iz smještajnih kapaciteta koje nije moguće vratiti u ljudski uporabu.

Moguća je upotreba alternativnih vrsta trava koje su prilagođene atmosferskim i drugim uvjetima u kojima je izgrađen golf-teren. Dobar odabir vrste trave nužan je kako bi se smanjila potrošnja vode. Zato su trave za toplu sezonu daleko najbolji izbor. Cynodon spp., Zoysia spp., Paspalum vaginatum i Buchloe dactyloides vrste su trava s najmanjim potrebama vode.

Uporaba bočate ili pak morske vode može se uvesti kao dodatak drugim izvorima vode. Priobalna trava Paspalum (troskot) iskazuje visoku otpornost na slanu vodu, ali je i bermudska trava prilično otporna.

Golf-klub Old Collier u mjestu Naples (Florida), gdje su posađene dvije nove vrste priobalne trave Paspalum na greenovima, izbijalištima, fairwayima i roughovima, upotrebljava morsku vodu za zalijevanje travnjaka, što je posebno važno u prostorima oko obalnih područja ${ }^{28}$. Međutim, na taj se način ne rješava problem zaslanjivanja podzemnih voda. Zbog toga se desalinizacija čini kao skuplje, ali prihvatljivije rješenje od navodnjavanja slanom vodom, pri čemu treba sagledati i potrošnju energije u postupku desalinizacije, što takve projekte dodatno poskupljuje i povećava njihov ugljični otisak.

Prikladno dizajnirani sustavi za zalijevanje, posebice u pogledu raspona (najmanje dvostruki ili trostruki), pokrivenosti (100 \% ili možda više), broju raspršivača i kapilarnoj distribuciji vode (npr. na pojasevima trave oko greena) preporučljivi su u svakoj situaciji oskudice vode $^{21}$.

Dio ušteda moguće je dobiti i promjenom ekološke svijesti igrača kojima intenzivno zelenilo trave u nevegetacijskim periodima godine nije presudno za igranje golfa, već je stvar navike i očekivanja. Razvoj ekološke svijesti pretpostavka je rješavanja ekoloških problema ${ }^{29}$.

\subsubsection{Primjena sredstva za uništavanje štetnika (pesticidi i biocidi)}

Uz to što se opterećuje postojeća vodoopskrbna mreža i direktno povećava zahvat najčešće ograničenih količina pitke vode iz prirodnih rezervoara, golfom se povećava mogućnost kontaminacije podzemnih ležišta pitke vode i otvorenih tokova aplikacijom gnojiva i biocida, pesticida i herbicida ${ }^{30,31,32}$. Količina korištenog gnojiva ovisi o: vrstama trave (specifične potrebe), vrsti tla, vrsti korištenog gnojiva (npr. gnojivo koje sadrži dušik može ga otpuštati sporije ili brže), brzini rasta trave, metodi primjene (npr. tekuće ili kruto), hranjivim sastojcima koji su već prisutni u tlu i - odstranjivanju pokošene trave ${ }^{33}$.

Istraživanja o ponašanju apliciranog gnojiva nisu brojna. Prema istraživanju ${ }^{30}$ na gotovo svim uzorcima vode prikupljenima u rijekama i jezerima u blizini golf-terena pronađene su količine pesticida više od dozvoljenih.

Jedno od njih provedeno u Padskoj dolini (Italija) ukazuje da se u dolini rijeke Pad (Po), nalazi 60 golf-igrališta s najmanje 18 rupa. Počevši od 2005. godine, radna skupina koju čine stručnjaci IGF-a (Talijanska golf-federacije) i GEE-a (Golf Environment Europe - Europska golf-asocijacija za okoliš) ispitivala je stvarnu potrošnju gnojiva, pesticida i vode na travnjacima pojedinih golf-igrališta. U suradnji s lokalnim upraviteljima bio je sastavljen ogledni uzorak od 16 golf-igrališta $(26,6 \%$ ukupnog broja), od čega 12 igrališta sa 18 , dva sa 27 te dva sa 36 rupa, prosječne površine 77 hektara. Prema prikupljenim podacima, prosječna godišnja potrošnja vode po golf-igralištu iznosi $1339,9 \mathrm{~m}^{3} / \mathrm{ha}-1$, a što se gnojiva i kemijskih sredstava tiče, podaci govore o potrošnji od 39,8 kg/ha-1 dušika (N), $6 \mathrm{~kg} / \mathrm{ha}-1$ fosfora $\left(\mathrm{P}_{2} \mathrm{O}_{5}\right), 33,3 \mathrm{~kg} / \mathrm{ha}-1$ kalija $\left(\mathrm{K}_{2} \mathrm{O}\right), 1,7 \mathrm{~kg} / \mathrm{ha}-1$ herbicida, $3,5 \mathrm{~kg} / \mathrm{ha}-1$ fungicida te $1,9 \mathrm{~kg} / \mathrm{ha}-1$ insekticida ${ }^{21}$.

Do devedesetih godina kroz pesticide u tlo i vode unosile su se velike količine kadmija i arsena kao teških metala, međutim uporaba pesticida, a time i teških metala 
posljednjih se godina smanjuje zbog prelaska na primjenu bioloških i sporotopivih pesticida ${ }^{33}$.

Dio pesticida primjenjuje se i za suzbijanje štetnika, uključujući i komarce. Alternativno je moguće smanjiti količinu pesticida uvođenjem zajednice šišmiša u prostor kao prirodnih neprijatelja komaraca.

Danas je na golf-igralištima u praksi primjena sporotopivih gnojiva s dugotrajnim djelovanjem jer je u tom slučaju ispiranje opasnih nitrata u podzemne vode mnogo manje ${ }^{7}$. lako je upitna smislenost usporedbe opterećenja po okoliš koje proizvodi poljoprivreda kojom se proizvodi hrana i opterećenja koje proizvodi golf-turizam, neki autori koji zagovaraju razvoj golf-industrije ${ }^{21}$ ističu kako se na travnatim površinama golf-igrališta, u okviru istih površina, upotrebljavaju manje količine gnojiva i fitosanitetskih proizvoda u odnosu na uobičajene intenzivne poljoprivredne kulture.

Zagovornici golf-turizma vrlo često kao snažan argument ističu činjenicu da golf-tereni manje opterećuju okoliš od korištenja zemljišta u poljoprivredne svrhe ${ }^{21}$. Međutim, bioetičari problem sagledavaju mnogo šire, budući da poljoprivreda proizvodi hranu u uvjetima svjetske gladi, a golf-resorti troše resurse za dokolicu ili ostvarivanja profita bogatih zemalja.

\subsubsection{Utjecaj izgradnje i korištenja golf- terena na bioraznolikost}

Golf-igrališta obuhvaćaju brojna staništa cijelog niza raznih biljnih i životinjskih vrsta, od kojih mnoge polako nestaju iz prirodnog okruženja kao posljedica narušavanja ili nestanka potrebnih prirodnih područja, lova te fitosanitetskih proizvoda koji se sve više primjenjuju u poljoprivredi.

$U$ većini slučajeva ${ }^{23}$ prilikom realizacije golf-projekata bioraznolikost životinjskih i biljnih vrsta postane žrtvom profita investitora.

Smanjenje bioraznolikosti raste zbog aktivnog igranja na području cijelog golf-terena, a posebice nakon uporabe pesticida zbog održavanje terena $u$ idealnom $i$ estetski igračima očekivanom stanju potpunog zelenila usprkos klimatskim promjenama i varijacijama godišnjih doba. Studije istraživanja ekološke svijesti golfera propituju njihovu ekološku osviještenost i usmjerenost na neuznemiravanje životnija i nedevastaciju biljnih vrsta prilikom igranja golfa ${ }^{34}$. Međutim, utjecaj na bioraznolikost veže se uz cijeli projekt izgradnje i održavanja golf-terena i smještajnih kapaciteta. Prisutnost golf-tu- rizma u prirodnom staništu, posebice prisutnost čovjeka i popratne opreme, uključujući i rasvjetu, neizbježno dovodi do promjena u ponašanju životinja, njihovoj reprodukciji, psihologiji i općem zdravlju te vodi do smrti većeg broja jedinki, neovisno o ponašanju samih golfera ${ }^{35}$. Nadalje, većina nestalnih životinjskih vrsta koje borave u zaštićenim područjima koristi samo igralište, kao i okolna područja, pri čemu rezervati nisu odvojeni otoci i njihova učinkovitost može se u znatnoj mjeri potencirati stvarajući „potporna” staništa u obliku spojnih koridora, kao što mogu biti drvoredi, živice, jarci ili staze nepokošene trave.

\subsubsection{Urbanizacija i prekomjerna apartmanizacija}

U destinacijama u kojima se razvija golf-turizam stvaraju se tzv. golfski klasteri, područja s pet ili više igrališta koja sa smještajnim kapacitetima u okolici čine prepoznatljiva turistička odredišta, pri čemu izdvojeni razvojni projekti teško uspijevaju.

Uz golf se često veže i prodaja nekretnina te je stoga investiranje u golfersko-turističku sferu unosnije od klasične investicije u nekretnine. Gradnja nekretnina, a posebice apartmana u sklopu golf-kompleksa opravdava se početnom nerentabilnošću golfa i amortizacije održavanja igrališta. Investiranje u klasično golf-igralište bez nekretnina podrazumijeva dugo vraćanje uloženog kapitala (i do 40 godina). što predstavlja velik rizik za investitore?

Uz apartmanizaciju, golf je u nekim sredinama postao izgovor za urbanizaciju, a česte su zamjerke da se područje planirano za golf zatvara, tj. izdvojeno razvija bez povezanosti s lokalnom zajednicom.

Izgradnja smještajnih kompleksa neizbježna je budući da su početna ulaganja u golf iznimno visoka, pri čemu se u prosjeku za jedno golf-igralište sa 18 polja ulaže oko 6.000 .000 eura. Zbog velikih ulaganja, procjenjuje se da je nivo rentabilnosti minimalno 15000 partija golfa godišnje pa se s pravom postavlja cilj da se zaradom igrališta pokriju troškovi izgradnje, a profit ostvari iznajmljivanjem smještajnih kapaciteta ${ }^{7}$.

Samo golf-igralište bez drugih sadržaja niskoprofitna je investicija. Ono je sredstvo prijenosa, ključ koji otvara vrata drugim investicijama (u graditeljstvu, turizmu, prometu itd.), jer golf-igralište bez okruženja zanimljivog prije i nakon igranja ne može privući dovoljan broj aktivnih igrača. Kao i u svakom drugom sportu, i u golfu je više rekreativaca nego profesionalaca pa im moraju 
biti ponuđeni drugi sadržaji, odnosno jačina veze golfigrališta i poslovne ponude u okolici presudna je za njegovu profitabilnost. Peter ističe da od ukupnog godišnjeg prihoda od golfa udio golf-igrališta iznosi samo $10 \%$. Preostalih $90 \%$ donose hoteli, restorani, trgovine, prijevoznici, graditelji, druge uslužne djelatnosti te svi ostali popratni sadržaji i akcesorne usluge ${ }^{8}$. Oslanjanje razvoja golfa na lokalnom stanovništvu pretpostavlja postojanje više srednje klase i visoke klase kojoj je blizak taj oblik sporta i rekreacije ${ }^{36}$.

U prilog kritičarima razvoja golf-turizma kao mogućeg paravana za apartmanizaciju prostora ide u prilog i činjenica da su isplativa samo ona golf-igrališta koja su smještena u blizini velikih turističkih središta, što osigurava dovoljnu fluktuaciju gostiju, odnosno ona igrališta koja su organizirana kao klubovi s velikim brojem stalnih članova. Peter ističe da u područjima gdje svakodnevno ne postoji velik broj igrača investitori privlače ljude ili ponudom kuća i stanova u blizini golf-igrališta ili na osnovi njihova boravka u hotelu tijekom odmora ${ }^{8}$.

S obzirom na to da je teško očekivati razvoj klupskog članstva u zaleđu Zadra, a i broj stalnih stanovnika kao ni sezonalnost gostiju u postojećim kapacitetima ne osigurava dovoljan broj potencijalnih korisnika golfterena, sve navedeno ukazuje na nužnost privlačenja gostiju ponudom vila i apartmana, a time i potencijalnu opasnost razvoja golf-terena u blizini PP-a Vransko jezero u zaleđu Biograda na Moru.

\subsection{Alternativne mogućnosti razvoja turističke destinacije i segmenata turizma uvažavajući vrijednost PP-a Vransko jezero}

lako je Vlada RH uložila znatne napore kako bi realizirala i operacionalizirala razvoj samo jednog iz segmenta proizvoda s izraženom perspektivnom razvoja i iako je Zadarska županija golf-turizam izabrala kao prioritet na kojem temelji razvoj, upravo zbog mogućega pogubnog utjecaja iscrpljivanja vode za navodnjavanje golf-terena, moguće salinizacije te ekološki neprihvatljive primijenjene kemijskih sredstava na travnatim površinama na krškom terenu i u blizini ornitološkog rezervata nužno je traženje alternative trenutačno proklamiranom putu razvoja. Usmjeravanjem na razvoj jednog segmenta uz nedovoljno pridavanje pažnje i mogućem razvoju drugih proizvoda s izraženom perspektivnom razvoja dovodi se u opasnost opstanak cijele ekološki vrijedne regije. Tim više što je kriza na svjetskom tržištu i recesija unazad nekoliko godina ozbiljno negativno utjecala na opstanak već razvijenih resorta s golf-terenima i bankrota u prestižnim destinacijama, a i dovela do propasti sličnih projekata u Hrvatskoj (projekt Marlera, Dolina kardinala i sl.).

U Zadarskoj županiji posebno je važno razmotriti sljedeće proizvode kao moguće alternative razvoju po prirodu vrlo opterećujućeg golf-turizma: zdravstveni i wellness-turizam, enologija, cikloturizam, pustolovni i sportski turizam i ekoturizam, gdje Hrvatska, a posebice Zadarska županija i grad Biograd na Moru još uvijek nedovoljno koriste svoje komparativne prednosti za razvoj ove skupine proizvoda. Naime, u svjetlu svega iznesenog o mogućem utjecaju golf-terena na okoliš, iznimno je važno pri planiranju razvoja pojedinih segmenata turizma imati na umu da jezera i druge zajezerene površine poput prirodnih močvara i bara, akumulacija i ribnjaka, pa čak i podzemnih voda stajaćica predstavljaju vrijedne i posebno osjetljive vodne resurse. Ovi sustavi specifični su po svojoj hidrologiji i ekologiji, što čini procese njihova upravljanja vrlo složenima i zahtjevnima, a time i traže posebnu mudrost i odgovornost pri promišljanju budućeg razvoja. Jezera imaju karakter ne samo posebno vrijednih staništa nego na neki način i živih organizama. Imaju svoju mladost, vitalno doba, starost i smrt te se jedino poznavanjem svih utjecajnih elemenata i njihovih međuodnosa mogu pronaći prikladne mjere kako bi se odložile neželjene promjene te primjereno valorizirale vrijednosti koje jezera imaju. Održivim razvojem turizma na ovoj destinaciji moguće je dati snažan stručni doprinos kako bi postojeće jezero što dulje imalo razdoblje svoje mladosti i vitalnosti, a da se planiranje novih urbanih vodnih sadržaja i sličnih sustava odvija na način kojim će se smanjiti moguće neželjene posljedice takvih zahvata, uvažavajući raznolike pritiske koji djeluju na jezerske sustave, poput utjecaja klimatskih promjena.

\section{Zaključak}

„Sunce i more" danas su dominantan turistički proizvod Zadarske županije i grada Biograda na Moru. Zadržavanje i unaprjeđenje postojeće pozicije na turističkom tržištu zahtijeva kontinuirano sadržajno obogaćivanje i povećanje kvalitete smještajne i uslužne ponude, odnosno produbljivanje destinacijskog lanca vrijednosti. 
S druge strane, današnja dominantna pozicija proizvoda „sunca i mora” istodobno je i osnovni razlog izrazite sezonalnosti turističke potražnje i koncentracije turističkog prometa na uski priobalni pojas. Budući da oslanjanje na proizvod „sunce i more” dugoročno neće pridonijeti znatnijem unaprjeđenju konkurentske pozicije kao turističke destinacije, a time ni povećanju turističke potrošnje ni boljem korištenju razvojnih potencijala, Zadarska županija i grad Biograd na Moru u razdoblju do 2020. godine moraju se pojačano okrenuti razvoju turističkih proizvoda koji će omogućiti ne samo veće korištenje raspoloživim kapacitetima izvan ljetnih mjeseci nego i aktiviranje turističkih potencijala. Odgovornost lokalnih vlasti grada Biograda na Moru i Zadarske županije za održivi razvoj turizma na tom području iznimno je velika. Potrebno je kritički razmotriti sadašnju strategiju razvoja koja se osniva na razvoju golf-turizma u sklopu svih opasnosti koje srednjoročno i dugoročno predstavlja razvoj tog segmenta turizma u ovom području ne samo na okoliš nego i cjelokupnost prirodne, kulturne, povijesne i društvene cjeline. Kroz provedene analize u radu je pokazano da Urbanističkim planom i Strategijom razvoja grada Biograda predviđena izgradnja golf-igrališta „Baštijunski brig” s pratećim ugostiteljsko-turističkim sadržajima nije u potpunosti usklađena s konceptom održivog razvoja turizma, posebice s aspekta ekološke, ekonomske i tehnološke održivosti, i da razvoj golf-turizma sa sigurnošću ne može garantirati kratkoročni razvoj i dobit, već je možda potencijalno srednjoročno i dugoročno ugrožena održivost razvoja turizma cijelog područja.

Nadalje, prenamjena prostora i povećanje lokalnih kapaciteta kroz gradnju golf-resorta „Baštijunski brig” uz gradnju klastera golf-igrališta nije u potpunosti usklađena $\mathrm{s}$ realnim mogućnostima okoliša. Zbog toga je mišljenje autora da planove izgradnje golf-terena na području Baštijunski brig i svih drugih klastera golfigrališta na području zadarskog zaleđa možda treba i napustiti uz prethodno provedenu sanaciju odlagališta otpada „Baštijunski brig”, koja ne bi trebala biti povezivana s izgradnjom golf-igrališta. Kritičko propitivanje sadašnje usmjerenosti turizma paralelno treba pratiti i operacionalizacija nove vizije i strateških razvojnih ciljeva, što, naravno, zahtijeva djelovanje na nekoliko ključnih područja što će, uz snažan angažman nositelja javne vlasti, osigurati pospješivanje konkurentske sposobnosti i percepcije turizma. Uspješno diferenciranje grada Biograda na Moru od konkurentskih destinacija treba temeljiti ponajviše na njegovanju prirodne i doživljajne autentičnosti, s naglaskom na kreativnost u razvoju proizvoda, destinacijskom pozicioniranju i komunikaciji s tržištem uz potpuno provođenje svih postulata menadžmenta održivog razvoja s osiguranom zaštitom okoliša.

U tom smislu razvoj cikloturizma, pustolovnog turizma, ekoturizma, a posebice „promatranja ptica” (engl. bird watching) uz snažnu oslonjenost na regionalne specifičnosti i prirodne vrednote predstavlja snažnu alternativu sadašnjem odabranom putu koji dugoročno nije održiv za okoliš.

Promotivne aktivnosti treba, prema mišljenju autora, preusmjeriti prema tzv. ekološki osviještenim istraživačima doživljaja koji se mogu pronaći među svim dobnim skupinama, razinama primanja, geografskim lokacijama i vremenu putovanja u godini. Uz marketinški jasno osmišljen segmentirani pristup s ciljanim porukama i promotivnim aktivnostima prema diferenciranim interesnim grupama moguće je podići i atraktivnost i konkurentnost destinacije. Sobzirom na to da postojeći dominantni imidž destinacije koja nudi gotovo isključivo "sunce i more” unutar limitiranih ljetnih mjeseci te tržišna komunikacija koja ga kontinuirano naglašava u ovom trenutku predstavljaju ograničenje u prodiranju do novih potrošačkih segmenata, koji svojim potrebama i preferencijama mogu pridonijeti produljenju turističke sezone, razvoj segmenta poput cikloturizma i ekoturizma koji su nisu nužno ograničeni samo na period od lipnja do rujna mogu pridonijeti prevladavanju problema sezonalnosti. Nužno je stoga provesti profesionalno strukturiranje županijskog i lokalnog turističkog brenda (s naglaskom na cjelogodišnje korištenje mogućnostima koje pruža Ornitološki rezervat, područje NATURA 2000 i PP Vransko jezero u smislu ekoturizma i pustolovnog turizma) i njegove arhitekture kako bi se promijenila percepcija emitivnog tržišta o Zadarskoj županiji i Biogradu na Moru kao destinaciji isključivo ljetnog odmora.

Svijest i vidljivost lokalne destinacije, ne samo u sezoni nego upravo i u predsezoni i posezoni, trebala bi imati posebnu pažnju u sljedećim godinama kako bi se razvijao pozitivan imidž i razvoj ekološki održive destinacije, što zahtijeva osmišljeno, intenzivno i koherentno djelovanje na svim ključnim tržištima. Biograd na Moru do 2020. godine mora evoluirati u destinaciju raznovrsnije turističke ponude za platežno sposobne goste i goste koji imaju motive dolaziti cijelu godinu. Novi turistički proizvodi moraju omogućiti produženje turističke sezone na dodatnih najmanje 60 dana. Premda je Biograd na Moru u Strategiji razvoja od 2013. do 2020. definiran kao destinacija za obiteljski turizam koji funkcionira u 
srpnju i kolovozu, nužno je daljnje razvijanje turističke ponude i za mjesece svibanj, lipanj, rujan i listopad, poštujući održivost turističkog razvoja. Tako bi Biograd na Moru mogao postati prepoznatljiva turistička destinacija, konkurentna i atraktivna za investicije, koja stvara radna mjesta i na održiv način upravlja razvojem na svojem cjelokupnom prostoru, njeguje kulturu kvalitete, a svojim gostima tijekom cijele godine pruža gostoljubivost, sigurnost i jedinstvenu autentičnost sadržaja i doživljaja.

\section{Literatura}

1. Smolčić Jurdana D. Management održivog razvoja - PPT prezentacije u sklopu MOR-a. Opatija: FTHM; 2017.

2. Strategija razvoja turizma Republike Hrvatske do 2020. godine. Narodne novine. 2013: 55.

3. Bartolucci M. i sur. Turizam i sport - razvojni aspekti. Zagreb: Školska knjiga; 2007.

4. Hudson S, Hudskon L. Golf Tourism. Oxford: Goodfellow Publisher Limited; 2009.

5. Šubić N. Golf: novi pokretač turističkog razvoja. Ugostiteljstvo i turizam. 1995; 43: 8-12.

6. Jeremić Z. Golf turizam: Izazovi i perspektive razvoja [doktorska disertacija]. Osijek: Sveučilište Josipa Jurja Strossmayera u Osijeku, Ekonomski fakultet; 2013. 206 str.

7. Radić Lakoš T, Goleš D, Šišak A. Analysis of the influence of the golf-course construction on the increase of usability of tourist capacities of Šibenik-Knin county and the increase of quality of tourist destination. U: 11. Hrvatska konferencija o kvaliteti; 2. Znanstveni skup Hrvatskog društva za kvalitetu „Inovativna primjena kvalitete”; 12. - 14. svibnja 2011.; Vodice.

8. Petar S. Razvoj turizma izgradnjom golf igrališta. Acta Turistica Nova. 2010; 4(1): 55-80.

9. Vlada RH. Program razvitka golfa kao elementa razvojne politike hrvatskog turizma. Istarska županija [internet]; 1999. Dostupno na: https://www.istra-istria.hr/index. php?id=978 (pristupljeno 15.9.2017.).

10. Panagopoulos T., et al. The Impact of Golf Course Development on a Constantly Changing Mediterranean Landscape. U: Proceedings of the 3rd IASME/WSEAS International Conference on Energy, Environment, Ecosystems \& Sustainable Development; 24. - 26. srpnja 2007.; Agios Nikolaos, Kreta, Grčka. 110-115.

11. Videira N, Correia A, Alves I, Ramires C, Subtil R, Martins V. Environmental and economic tools to support sustainable golf tourism: The Algarve experience, Portugal. Tourism and Hospitality Research. 2006; 6(3): 204-217.
12. Alcina d.o.o, Nizić D. Strategija razvoja turizma grada Biograda $n / m$ za razdoblje od 2015. do 2020. godine [internet]. Zagreb: Alcina d.o.o.; 2015. Dostupno na: http://www.biogradnamoru.hr/images/dokumenti/projekti/Strategija-razvoja-turizma-BnM-do-2020_v0.pdf (pristupljeno 15.9.2017.).

13. Galaso I. Studija utjecaja na okoliš za golf igralište „Baštijunski brig”, Biograd n/m. Zagreb: Fakultet strojarstva i brodogradnje Sveučilišta u Zagrebu; 2010.

14. Grad Biograd na moru. Odluka o Prostornom planu uređenja Grada Biograda na Moru (pročišćeni tekst). Službeni glasnik Grada Biograda na Moru [internet]. 10. listopada 2016.; 8: 321-372. Dostupno na: http://www.biogradnamoru.hr/images/sluzbeni-glasnik/2016/08-16. pdf (pristupljeno 15.9.2017.).

15. Arheo d.o.o. Urbanistički plan uređenja golf igrališta „Baštijunski brig”. Zagreb: Arheo d.o.o.; 2009. 29 str. Dostupno na http://www.biogradnamoru.hr/images/ dokumenti/prostorni_planovi/Urbanisticki_planovi_uredenja_UPU/UPU_golf_igralista/I_OBRAZLOZENJE_1265292555.pdf (pristupljeno 15.9.2017.).

16. Javna ustanova Park prirode Vransko jezero [internet]; 2017. Dostupno na: http://www.pp-vransko-jezero.hr/ $\mathrm{hr} /$ (pristupljeno 15.9.2017.).

17. Radović D. Mišljenje o utjecaju izgradnje golf igrališta Baštijunski Brig. Zagreb: Hrvatsko ornitološko društvo [internet]; 2010. Dostupno na: http://www.ulika.net/1/ ornitologija/golf-bastijun.pdf (pristupljeno 15.9.2017.).

18. Kelava M. Tko s kime i zbog čega igra golf. H-alter. 2010. Dostupno na: http://www.h-alter.org/vijesti/tko-s-kimeigra-golf (pristupljeno 15.9.2017.).

19. Uprava za zaštitu prirode Ministarstva kulture. Mišljenje - klasa 612-07/09-01/1710 od 8. veljače 2010. Zagreb: Republika Hrvatska, Ministarstvo kulture; 2010. Dostupno na http://www.min-kulture.hr/userdocsimages/priroda\%20nova/mi\%C5\%A1ljenje,\%20velja\%C4\%8Da.pdf (pristupljeno 15.9.2017.).

20. Javna ustanova Park prirode Vransko jezero. Plan upravljanja Parkom prirode Vransko jezero [internet]. Biograd na moru: Javna ustanova Park prirode Vransko jezero; 2010.

21. Curić B. Analiza okvirnih mogućnosti razvoja golfa na području Istarske županije. Pula: Istra Golf Dizajn d.o.o.; 2007.

22. Socijalistička radnička partija Hrvatske. Golf u Istri [internet]. Zagreb: Socijalistička radnička partija Hrvatske; 2. veljače 2013. Dostupno na: http://www.srp.hr/golf-uistri/ (pristupljeno 15.9.2017.).

23. Jelenković E. Golfturizam [diplomski rad]. Pula: Sveučilište Jurja Dobrile u Puli, Fakultet ekonomije i turizma „Dr. Mijo Mirković"; 2015. 62 str.

24. Wakida FT, Lerner DN. Non-agricultural sources of groundwater nitrate: a review and case study. Water res. 2005; 39(1): 3-16.

25. Flury M. Experimental evidence of transport of pesticides through field soils - a review. J Environ Qual. 1996; 25(1): 25-45.

26. Golfigrališta: rukuj s oprezom. Volim Lošinj; 13. lipnja 2016. Dostupno na http://www.volim-losinj.org/politika/2584golf-rukuj-s-oprezom (pristupljeno 1.9.2017.). 
27. Cardenas-Lailhacar B, Dukes MD, Miller GL. Sensor-based automation of irrigation on bermudagrass during wet weather conditions. J Irrig Drain Eng. 2008; 134(2): 120-128.

28. The Old Collier golf club [internet]. Naples: Old Collier club; 2017. Dostupno na http://www.theoldcolliergc. com/ (pristupljeno 15.9.2017.).

29. Afrić K. Ekološka svijest - pretpostavka rješavanja ekoloških problema. Ekonomski pregled. 2002; 53(5-6): 578-594.

30. United States Geological Survey. Pesticide in the Nations Streams and Ground Water. Water Online; March 9, 2006. Dostupno na https://www.wateronline.com/doc/reportpesticides-in-the-nations-streams-and-0001 (pristupljeno 1.3.2017.).

31. Liu J, Yang W. Water sustainability for China and beyond. Science. 2012; 337(6095): 649-650.
32. Branham B, Miltner E, Rieke P. Potential groundwater contamination from pesticides and fertilizers used on golf courses. USGA Green Section Record. 1995; 33(1): 33-37.

33. PuYang X, Gao C, Han L. Risk assessment of heavy metals in water and two fish species from Golf Course Ponds in Beijing, China. B Environ Contam Tox. 2015; 94(4): 437-443.

34. Walker M, Kent A. Do fans care? Assessing the influence of corporate social responsibility on consumer attitudes in the sport industry. J Sport Manage. 2009; 23(6): 743-769.

35. Tanner RA, Gange AC. Effects of golf courses on local biodiversity. Landscape Urban Plan. 2005; 71(2-4): 137-146.

36. Cohen E. Golf in Thailand: From sport to business. Southeast Asian Journal of Social Science. 1995; 23(2): 1-17. 


\section{ANALYSIS OF GOLF TOURISM DEVELOPMENT IN TERMS OF SUSTAINABLE DEVELOPMENT MANAGEMENT}

\section{Abstract}

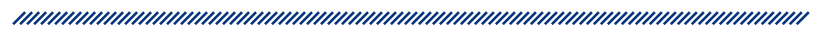

The concept of sustainable development of all segments of society presumes the establishment of a positive relationship between economics and ecology, alongside bioethical responsible behaviour of all the involved stakeholders. The interdependence of tourism and the environment with the aim of achieving sustainable development involves linking the development policy with natural resources management, but also increasing the local capacity in accordance with realistic environmental capabilities. The main aim of this paper was to critically analyse - from the viewpoint of the theoretical concept of planning sustainable tourism development - the development plan of the tourist destination Biograd na Moru, in particular the sustainability of the planned development of golf tourism at the Baštijunski brig site, and to critically analyse the plans for the construction of a golf course with accompanying catering and tourist amenities from the aspect of ecological, sociocultural, economic and technological sustainability as integral segments of development sustainability.

The additional aim of the paper was to carry out a conformity analysis of the increase of local tourist capacities through the construction of golf resorts within the realistic possibilities of the environment. This paper uses secondary sources of information that were subjected to induction, deduction, analysis and synthesis procedures, as well as to comparison, descriptor and classification methods. In the practical part, an on-thespot inspection of the project location and potential critical points was carried out, primarily in the boundary areas between the future golf resort, the nature park Vransko Lake, Baštijunski brig waste landfill and the ecological network area of HR1000024 Ravni kotari, HR2000914 Ornithological reserve, Vransko Lake and Jasen for the purpose of obtaining immediate insight into the situation and the assessment of the potential impact of the project on the environment.

According to the author, the results of the analysis show that the planned construction of the Baštijunski brig golf course with accompanying catering and tourist amenities is not fully adjusted with the concept of sustainable tourism development, especially from the aspect of ecological, economic and technological sustainability, and can lead to the transformation of the tourist destination. The analysis also points to the conclusion that planned repurposing of the site and increase of local capacities through the construction of the Baštijunski brig golf resort, along with the construction of cluster golf courses at the county level, is not fully in line with the realistic possibilities of the environment. In this regard, the development of cyclotourism, adventure tourism, ecotourism, and in particular bird watching, with a strong reliance on regional specificities and natural riches, provides a strong alternative to the current development path that could not be environmentally sustainable in the long term and it is questionable whether it contributes to sustainable development of tourism.

Keywords: sustainable development management, golf tourism, environmental pollution, nature park, NATURA 2000 